\title{
The Yin and Yang-Like Clinical Implications of the CDKN2A/ARF/CDKN2B Gene Cluster in Acute Lymphoblastic Leukemia
}

\author{
Celia González-Gil ${ }^{1,+}{ }^{,}$, Jordi Ribera ${ }^{1,+}$, Josep Maria Ribera ${ }^{1,2}{ }^{\oplus}$ and Eulàlia Genescà ${ }^{1, *}$ \\ 1 Josep Carreras Leukaemia Research Institute (IJC), Campus ICO-Hospital Germans Trias i Pujol, \\ Universitat Autònoma de Barcelona (UAB), 08916 Badalona, Spain; cgonzalez@carrerasresearch.org (C.G.-G.); \\ jribera@carrerasresearch.org (J.R.); jribera@iconcologia.net (J.M.R.) \\ 2 Clinical Hematology Department, ICO-Hospital Germans Trias i Pujol, 08916 Badalona, Spain \\ * Correspondence: egenesca@carrerasresearch.org; Tel.: +34-93-557-28-08 \\ + Equally Contribution.
}

Citation: González-Gil, C.; Ribera, J.; Ribera, J.M.; Genescà, E. The Yin and Yang-Like Clinical Implications of the CDKN2A/ARF/CDKN2B Gene Cluster in Acute Lymphoblastic Leukemia. Genes 2021, 12, 79. https://doi.org/ 10.3390/genes12010079

Received: 20 November 2020

Accepted: 5 January 2021

Published: 9 January 2021

Publisher's Note: MDPI stays neutral with regard to jurisdictional clai$\mathrm{ms}$ in published maps and institutional affiliations.

Copyright: $\odot 2021$ by the authors. Licensee MDPI, Basel, Switzerland. This article is an open access article distributed under the terms and conditions of the Creative Commons Attribution (CC BY) license (https:// creativecommons.org/licenses/by/ $4.0 /)$.

\begin{abstract}
Acute lymphoblastic leukemia (ALL) is a malignant clonal expansion of lymphoid hematopoietic precursors that exhibit developmental arrest at varying stages of differentiation. Similar to what occurs in solid cancers, transformation of normal hematopoietic precursors is governed by a multistep oncogenic process that drives initiation, clonal expansion and metastasis. In this process, alterations in genes encoding proteins that govern processes such as cell proliferation, differentiation, and growth provide us with some of the clearest mechanistic insights into how and why cancer arises. In such a scenario, deletions in the 9p21.3 cluster involving CDKN2A/ARF/CDKN2B genes arise as one of the oncogenic hallmarks of ALL. Deletions in this region are the most frequent structural alteration in T-cell acute lymphoblastic leukemia (T-ALL) and account for roughly $30 \%$ of copy number alterations found in B-cell-precursor acute lymphoblastic leukemia (BCP-ALL). Here, we review the literature concerning the involvement of the $C D K N 2 A / B$ genes as a prognosis marker of good or bad response in the two ALL subtypes (BCP-ALL and T-ALL). We compare frequencies observed in studies performed on several ALL cohorts (adult and child), which mainly consider genetic data produced by genomic techniques. We also summarize what we have learned from mouse models designed to evaluate the functional involvement of the gene cluster in ALL development and in relapse/resistance to treatment. Finally, we examine the range of possibilities for targeting the abnormal function of the protein-coding genes of this cluster and their potential to act as anti-leukemic agents in patients.
\end{abstract}

Keywords: acute lymphoblastic leukemia; del(9p21.3); prognosis; leukemogenesis; treatment

\section{Introduction}

Acute lymphoblastic leukemia (ALL) is a malignant clonal expansion of lymphoid hematopoietic precursors that exhibit developmental arrest at varying stages of differentiation, thereby partially recapitulating normal lymphoid ontogeny. Two subtypes are defined, according to which lymphoid progenitor is affected: B-cell-precursor ALL (BCP-ALL) and T-cell ALL (T-ALL). The incidence of ALL differs with age, whereby there is an early peak at 4 to 5 years (incidence of four to five per 100,000 people per year), a decline in young adults, followed by a slight increase after 50 years of age (incidence of up to two per 100,000 people per year) (www.seer.cancer.gov/statistics). Survival rates are lower in adults than in children. The improvement of treatment protocols over the last ten years has transformed pediatric ALL into a highly curable disease with long-term survival rates above $90 \%$ [1]. In contrast, long-term adult overall survival (OS) is $35 \%$ to $45 \%$ [2].

Similar to what occurs in solid cancers, transformation of normal hematopoietic precursors is governed by a multistep oncogenic process that drives initiation, clonal 
expansion and metastasis. In this process, alterations in genes encoding proteins that govern processes such as cell proliferation, differentiation, and growth provide us with some of the clearest mechanistic insights into how and why cancer arises. In such a scenario, deletions in the 9p21.3 cluster involving CDKN2A/ARF/CDKN2B (hereafter CDKN2A/B) genes arise as one of the oncogenic hallmarks of ALL. Deletions in this region are the most frequent structural alteration in T-ALL and account for roughly $30 \%$ of copy number alterations found in BCP-ALL. The proteins encoded by the $C D K N 2 A / B$ genes belong to the INK4 family of CDK inhibitors, which block the ability of the tandem cyclin DCDK4/CDK6 kinases to inactivate Retinoblastoma (RB) growth-suppressive functions [3]. The founding member is P16-INK4a [3]. Intriguingly, the CDKNA/B locus encodes a second, structurally and functionally unrelated protein, the alternative reading frame (ARF) or P14 ${ }^{\mathrm{ARF}}$, which is also a potent tumor suppressor $[4,5]$. The ARF protein activates TP53 by binding directly to the TP53-negative regulator, MDM2 [6,7]. Thus, one locus encodes two proteins that functionally interface with RB and TP53, which are two other key tumor suppressors that drive oncogenesis.

Here, we review the literature concerning the involvement of the 9p21.3 locus containing the $C D K N 2 A / B$ genes as a prognostic marker of good or bad response in the two ALL subtypes (BCP-ALL and T-ALL). We compare frequencies observed in studies performed on several ALL cohorts (adult and child), which mainly consider genetic data produced by genomic techniques. We also summarize what we have learned from mouse models designed to evaluate the functional involvement of the gene cluster in ALL development and in relapse/resistance to treatment. Finally, we examine the range of possibilities for targeting the abnormal function of the protein-coding genes of this cluster and their potential to act as anti-leukemic agents in patients. It is important to note that the genetic studies in ALL have mostly analyzed the impact of the locus, rather than the specific contribution of the $A R F$ gene. However, the functional studies highlighting the contribution of the locus in ALL leukemogenesis rely on the specific role of the ARF protein in this disease.

\section{Genetic and Epigenetic View of the $C D K N 2 A / B$ Gene Cluster in ALL}

\subsection{CDKN2A/B Gene Cluster Organization and Transcripts}

The cyclin dependent kinase inhibitor $2 \mathrm{~A}(C D K N 2 A)$ gene, also known as INK4A or $P 16-I N K 4 A$, and its paralog, cyclin dependent kinase inhibitor 2B (CDKN2B), or INK4B or $P 15-I N K 4 B$, are located on chromosome nine in the 9p21.3 cytogenetic band (information at https:/ /www.ncbi.nlm.nih.gov/gene. ID: 1029). The two genes are arranged in tandem in the adjacent DNA and are transcribed on the anti-sense strand (Figure 1A). The protein products of these genes, $\mathrm{P} 16$ and P15, are almost identical in their structure and biochemical properties and act as specific inhibitors of CDK4/6 kinases [3,7], suggesting that the genes arose from a duplication event during evolution. CDKN2A generates several transcript variants that add a level of complexity and diversity to this gene cluster. Up to 14 different transcripts have been identified in silico, including protein-coding genes (isoforms) and non-coding RNA (information at https: / / www.ensembl.org/Homo_sapiens/Gene, ID: CDKN2A ENSG00000147889). However, only three alternatively spliced variants encoding proteins have been cloned from cells and demonstrated to be functional, two of which, P12 and P16\%, are structurally related isoforms that act as inhibitors of CDK4 kinase. High levels of $P 16 \gamma$ expression are detected in primary T-ALL samples and in neuroblastoma cell lines [8]. The $P 12$ transcript is exclusively expressed in the human pancreas [9]. The third transcript, the alternative reading frame $(A R F)$ gene, also known as $P 14^{A R F}$, is produced from the two alternative first exons joined to the $C D K N 2 A$ exon two at the same acceptor site but in a different reading frame, resulting in a completely different protein [4] (Figure 1B). 
A

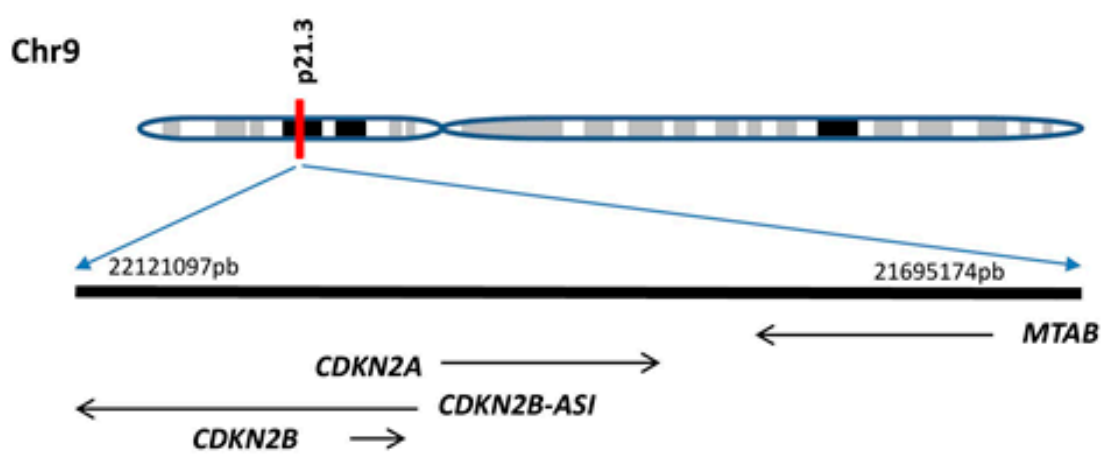

B

\section{CDKN2A transcripts}

$$
\begin{aligned}
& \text { TRV 4/ARF (132 aa) } \\
& \text { TRV 1/p16 (156 aa) } \\
& \text { TRV 5/p16 y (167 aa) } \\
& \text { TRV 3/p12 (116 aa) }
\end{aligned}
$$

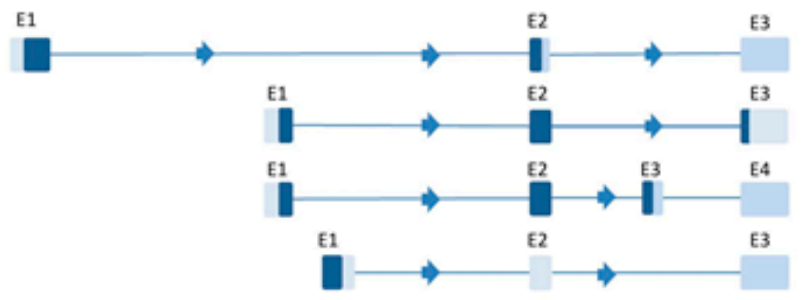

\section{CDKN2B transcripts}

$$
\begin{aligned}
& \text { TRV 2/p10 (78 aa) } \\
& \text { TRV 1/p15 (138 aa) }
\end{aligned}
$$

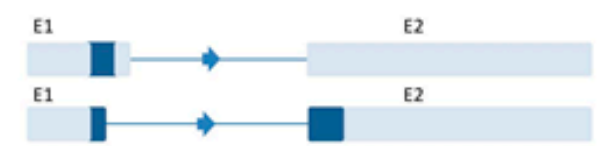

coding sequence non-coding sequence

Figure 1. Genomic organization of the 9p21.3 locus and expressed genes (A) Localization and orientation of the $C D K N 2 A / A R F / C D K N 2 B$ gene cluster (B) Alternative transcripts (and proteins) produced by different CDKN2A or CDKN2B promoter usage.

In the case of $C D K N 2 B$, two distinct transcripts are generated by alternative splicing. One of these is a non-coding protein (information at https:/ / www.ensembl.org/Homo_ sapiens /Gene, ID: CDKN2BENSG00000147883), while the other, $P 10$, is an alternatively spliced transcript of $C D K N 2 B$ that is ubiquitously expressed in normal and tumor cell lines [10]. The P10 protein product arises from a splicing defect in the $5^{\prime}$ donor site of intron one of $C D K N 2 B$, followed by a stop codon that is 79 nucleotides from the normally used splice site junction [10] (Figure 1B).

\subsection{9p21.3 Deletion in ALL}

\subsubsection{Methods to Detect the Alteration and Possible Origin}

The established methods for detecting structural alterations in hematology are karyotyping and fluorescence in situ hybridization (FISH). These allow detection of structural and numerical alterations with sizes of $>5 \mathrm{Mb}$ and $>150 \mathrm{~kb}$, respectively. However, both techniques are disadvantaged by their limited resolution, and often provide only a partial view of the full spectrum of alterations present in ALL patients. In the last 15 years, the use of high-throughput techniques such as the comparative genomic hybridization array (CGHa), the single nucleotide polymorphism array (SNPa) or, most recently, the next generation sequencing (NGS) technique, have helped refine frequencies of this alteration in BCP-ALL and T-ALL acute leukemias.

It has been postulated that illegitimate function of the recombination-activating gene (RAG) complex, whose normal physiological activity mediates $V(D) J$ recombination, may be behind the deletions in the $C D K N 2 A / B$ gene cluster and the many other recurrent ALL deletions, for example, IKZF1 (IKAROS), a key transcription factor that regulates 
the commitment of hematopoietic precursors in B cells [11]. The breakpoints of these deletions often localize in the recombination signal sequence (RSS) that is recognized by the RAG. The structure of the junctions is compatible with typical RAG double-strand DNA breaks [12-16]. However, the RSS sequences have not been found in all the breakpoints studied, raising the possibility that, in a small subset of lymphoid leukemias, the 9p21.3 deletions are caused by a mechanism other than illegitimate V[D]J recombination [13,14].

\subsection{2. del(9p21.3) in BCP-ALL}

In BCP-ALL as a whole, $C D K N 2 A / B$ deletions are the most common secondary genetic event. A preferential loss of the maternal allele has been documented, suggesting that germline variants in that allele may be behind these large loss biases [17]. More importantly, $\operatorname{del}(9 \mathrm{p} 21.3)$ is correlated with a lower level of gene expression, even in patients with hemizygous losses $[18,19]$. Overall, the frequency of $C D K N 2 A / B$ losses ranges from $15 \%$ to $35 \%$ in children and from $30 \%$ to $45 \%$ in adults, the losses being more frequent in high-risk patients of all ages (Tables 1 and 2). The relatively low frequency of the $C D K N 2 A / B$ deletion within the ETV6-RUNX1 and the high hyperdiploidy subgroups, which are both more prevalent in pediatric than in adult BCP-ALL, together with the high frequency of the deletion seen in BCR-ABL1, which characterizes a frequent genetic subgroup found in adult cases, may account for these age-related differences [20]. However, other studies have found no differences in the incidence of $C D K N 2 A / B$ loss between children and adults [21,22]. Other cytogenetic subgroups in which $C D K N 2 A / B$ deletions are more prevalent in BCP-ALL are the Philadelphia chromosome (Ph)-positive $\left(\mathrm{Ph}^{+}\right)$[23-27], the Ph-like [25,27-29], the IGH-ID4 [30] and the PAX5 P80R [31,32] subtypes. More recently, a significant association has been identified between $C D K N 2 A / B$ losses and IKZF1 deletions in $\mathrm{Ph}^{+}$patients [23] and in $\mathrm{Ph}$-negative $\left(\mathrm{Ph}^{-}\right)$patients associated with JAK2 mutations $[19,27,33-35]$. However, the most frequent concomitant alterations in patients with $\operatorname{del}(9 \mathrm{p} 21.3)$ are PAX5 deletions due to the recurrent losses of $9 p$ [27].

BCP-ALL presents with roughly equal proportions of heterozygous and homozygous $C D K N 2 A / B$ deletions. In addition, the presence of multiple clones harboring heterozygous and / or homozygous losses at diagnosis, and other clones with wt $C D K N 2 A / B$, has been noted [76,77]. This clonal heterogeneity masks the results obtained by techniques that use bulk leukemia, such as multiplex ligation-dependent probe amplification (MLPA) or $\mathrm{SNPa}$, and raises the question of whether, for instance, homozygous losses may be more critical to BCP-ALL progression than monoallelic ones [78-80]. Finally, in approximately $80 \%$ of cases, the minimum deleted region seen in BCP-ALL patients affects both genes. In the other $20 \%$ of cases, there is selective loss of one of the two genes, or simultaneous loss of both $C D K N 2 A / B$ genes but at different gene dosages (monoallelic vs. biallelic deletion) (Programa Español de Tratamiento en Hematología (PETHEMA) group; data not published). 
Table 1. Frequency and clinical impact of the $C D K N 2 A / B$ gene deletions in childhood acute lymphoblastic leukemia (ALL).

\begin{tabular}{|c|c|c|c|c|c|c|c|c|}
\hline Reference & Trial or Patient Origin (Period) & $\begin{array}{c}\text { Cohort } \\
\text { Size }\end{array}$ & Age (y) & Type of ALL & Frequency del (Method) & $\mathrm{EFS} / \mathrm{DFS} / \mathrm{RFS}(\mathrm{p})$ & OS (p) & CIR (p) \\
\hline$[36]$ & $\begin{array}{l}\text { CCG-1881, } 1882,1891,1922 \\
\text { (1988 to 1995) }\end{array}$ & 864 & $1-18$ & ВСР & $\begin{array}{l}9 \text { p abn. } 12 \% \\
\text { (Karyotyping) }\end{array}$ & $\begin{array}{l}\text { Univariate: EFS 6y-9p abn 63\% vs. no } \\
9 \text { p abn } 77 \%(p=0.0004)\end{array}$ & - & - \\
\hline$[37]$ & $(1987-1997)$ & 194 & $1-15$ & $\mathrm{BCP}$ & $\begin{array}{c}\text { CDKN2A del homo 24\%, } \\
\text { ARF del homo 27\%, } \\
\text { CDKN2B del homo 18\% } \\
\text { (Southern blot, SSCP, Sanger } \\
\text { sequencing) }\end{array}$ & $\begin{array}{c}\text { Univariate: } \text { EFS CDKN2A del homo } \\
0.58 \text { vs. } 0.77(p<0.001) \\
\text { Multivariate: CDKN2A del homo } \\
\text { poor }(p<0.01)\end{array}$ & - & - \\
\hline$[38]$ & $\begin{array}{l}\text { DCOG ALL8 and } 9 \\
(1991-2004)\end{array}$ & 109 & $0-17$ & $\mathrm{BCP}$ & $\begin{array}{c}\text { CDKN2A/B del 34\% } \\
\text { (FISH) }\end{array}$ & - & $\begin{array}{c}\text { Univariate: } 4 \mathrm{y}-\mathrm{CDKN} 2 \mathrm{~A} / \mathrm{B} \text { del } \\
80 \% \text { vs. } 87 \%(p=\mathrm{ns}) \\
\text { Multivariate: } \mathrm{CDKN} 2 \mathrm{~A} / \mathrm{B} \text { del } \\
\text { HR }=1.254(p=0.652)\end{array}$ & $\begin{array}{l}\text { Univariate: } 4 \mathrm{y}-\mathrm{CDKN} 2 \mathrm{~A} / \mathrm{B} \\
\text { del } 73 \% \text { vs. } 74 \%(p=\mathrm{ns}) \\
\text { Multivariate: } \mathrm{CDKN} 2 \mathrm{~A} / \mathrm{B} \\
\text { del } \mathrm{HR}=1.251(p=0.608) \\
\end{array}$ \\
\hline [39] & $\begin{array}{l}\text { EORTC } 58881 \text { and } 58951 \\
\quad(1989-2001)\end{array}$ & 227 & $0-17$ & $\mathrm{BCP}$ & $\begin{array}{l}\text { CDKN2A del } 31 \%, \\
\text { CDKN2B del } 23 \% \\
\text { (qPCR) }\end{array}$ & $\begin{array}{l}\text { Univariate: 6yEFS-CDKN2A del } \\
\text { homo } 68 \% \text { vs. CDKN2A del hetero } \\
80 \% \text { vs. CDKN2A wt } 75 \%(p=\text { ns) }\end{array}$ & $\begin{array}{l}\text { Univariate: CDKN2A del homo } \\
82 \% \text { vs. CDKN2A del hetero } 90 \% \\
\text { vs. wt } 87 \%(p=\text { ns) }\end{array}$ & $\begin{array}{l}\text { Univariate: CDKN2A del } \\
\text { homo } 11 \text { vs. CDKN2A del } \\
\text { hetero } 5 \text { vs. wt } 32(p=\text { ns) }\end{array}$ \\
\hline [40] & $\begin{array}{l}\text { Disc. COG P9906 (2000-2003) } \\
\text { Val. multiple COG protocols } \\
\text { (1986-2007) }\end{array}$ & 479 & $<18$ & $\begin{array}{c}\text { Disc: } 221 \text { high-risk BCP } \\
\text { Val: } 258 \mathrm{BCP}\end{array}$ & $\begin{array}{l}\text { CDKN2A/B del } 46 \% \text { disc. } \\
\text { CDKN2A/B del } 38 \% \text { val. } \\
\text { (SNPa) }\end{array}$ & $\begin{array}{l}\text { Univariate: ns (outcome data } \\
\text { not shown) }\end{array}$ & $\begin{array}{l}\text { Univariate: ns (outcome data } \\
\text { not shown) }\end{array}$ & $\begin{array}{l}\text { Univariate: ns (outcome } \\
\text { data not shown) }\end{array}$ \\
\hline [41] & $\begin{array}{l}\text { NOPHO2000 } \\
(2002-2006)\end{array}$ & 452 & $1-14$ & $\mathrm{BCP}$ & $\begin{array}{l}\text { CDKN2A/B del } 16 \% \\
\text { (FISH) }\end{array}$ & $\begin{array}{l}\text { Univariate: } 5 \text { yEFS-CDKN2A/B del } \\
\text { homo 76\% vs. CDKN2A/B del hetero } \\
76 \% \text { vs. CDKN2A/B wt } 83 \% \\
(p=0.330)\end{array}$ & - & - \\
\hline [43] & $\begin{array}{l}\text { PETHEMA } \\
(1996-2014)\end{array}$ & 115 & $0-17$ & $\mathrm{BCP}$ & $\begin{array}{l}\text { CDKN2A/B del 33\% } \\
\text { (CGH array) }\end{array}$ & $\begin{array}{l}\text { Univariate: EFS ns (outcome data } \\
\text { not shown) }\end{array}$ & $\begin{array}{l}\text { Univariate: ns (outcome data } \\
\text { not shown) }\end{array}$ & $\begin{array}{l}\text { Univariate: ns (outcome } \\
\text { data not shown) }\end{array}$ \\
\hline [19] & $\begin{array}{l}\text { ALL IC BFM } 2002 \text { and } 2009 \\
\text { (2002-2017) }\end{array}$ & 641 & $2-12$ & $\mathrm{BCP}$ & $\begin{array}{l}\text { CDKN2A del } 26 \% \\
\text { CDKN2B del } 22 \% \\
\text { (MLPA, SNPa) }\end{array}$ & $\begin{array}{c}\text { Univariate: RFS CDKN2A del homo } \\
\text { HR 2.21 }(p=0.028) \\
\text { Multivariate: CDKN2A del homo } \\
\text { HR }=3.09(p=0.007)\end{array}$ & $\begin{array}{l}\text { Univariate: } 2 \mathrm{y} \text {-CDKN2A } / \mathrm{B} \text { del } \\
85 \% \text { vs. wt } 88 \%(p=0.560)\end{array}$ & - \\
\hline [44] & $\begin{array}{l}\text { GIMEMA 2000-0904-1104-1308 } \\
\text { and AIEOP ALL 2000, } \\
\text { AIEOP-BFM ALL 2009 } \\
(2000-2018)\end{array}$ & 157 & $\begin{array}{c}1-15(n= \\
45)\end{array}$ & $\begin{array}{c}\text { BCP negative for } \\
\text { BCR-ABL1, } \\
\text { ETV6-RUNX1, } \\
\text { TCF3-PBX1 or KMT2Ar }\end{array}$ & $\begin{array}{l}\text { CDKN2A/B del } 11 \% \\
\text { (MLPA) }\end{array}$ & $\begin{array}{c}\text { Multivariate (children }+\mathrm{AYA}+ \\
\text { adults): CDKN2A/B/RB1 HR }=2.12 \\
(p=0.048)\end{array}$ & $\begin{array}{c}\text { Univariate: ns } \\
\text { (outcome data not shown) }\end{array}$ & $\begin{array}{l}\text { Univariate: ns (outcome } \\
\text { data not shown) }\end{array}$ \\
\hline [45] & $\begin{array}{l}\text { ANZCHOG ALL8 } \\
(2002-2011)\end{array}$ & 475 & $1-18$ & Non-high-risk $B C P$ & $\begin{array}{c}\text { CDKN2A/B del 36\% } \\
\text { (MLPA) }\end{array}$ & $\begin{array}{l}\text { Univariate: 7y-EFS CDKN2A/B del } \\
\text { homo } 77 \% \text { vs. del hetero } 81 \% \text { vs. wt } \\
\quad 80 \%(p=\text { ns) }\end{array}$ & $\begin{array}{c}\text { Univariate: } 7 \mathrm{y} \text {-CDKN2A/B del } \\
\text { homo } 87 \% \text { vs. del hetero } 93 \% \text { vs. } \\
\text { wt } 94 \%(p<0.05)\end{array}$ & $\begin{array}{c}\text { Univariate: } 7 \mathrm{y} \text {-CDKN2A/B } \\
\text { del homo } 18 \% \text { vs. del heter } \\
17 \% \text { vs. wt } 17 \% \text { ( } p=\text { ns) }\end{array}$ \\
\hline [27] & $\begin{array}{l}\text { DCOG-ALL10 } \\
(2004-2012)\end{array}$ & 515 & $1-18$ & $\mathrm{BC}$ & $\begin{array}{l}\text { CDKN2A/B del 33\% } \\
\text { (MLPA) }\end{array}$ & $\begin{array}{l}\text { Univariate: EFS CDKN2A/B del } 79 \% \\
\text { vs. wt } 87 \%(p=\text { ns) }\end{array}$ & $\begin{array}{c}\text { Univariate: ns (outcome data not } \\
\text { shown) }\end{array}$ & $\begin{array}{l}\text { Univariate: CDKN2A/B de } \\
17 \% \text { vs. wt } 10 \%(p=\text { ns })\end{array}$ \\
\hline [46] & $\begin{array}{c}\text { ALLR3 } \\
(2003-2013)\end{array}$ & 192 & $1-18$ & 1st (late) relapse BCP & $\begin{array}{l}\text { CDKN2A/B del 22\% } \\
\text { (MLPA) }\end{array}$ & $\begin{array}{c}\text { Univariate: } 5 \mathrm{y}-\mathrm{CDKN} 2 \mathrm{~A} / \mathrm{B} \text { del } 63 \% \\
\text { vs. wt } 62 \%(p=0.75)\end{array}$ & $\begin{array}{c}\text { Univariate: } 5 \mathrm{y}-\mathrm{CDKN} 2 \mathrm{~A} / \mathrm{B} \text { del } \\
69 \% \text { vs. wt } 75 \%(p=0.26)\end{array}$ & \\
\hline
\end{tabular}


Table 1. Cont

\begin{tabular}{|c|c|c|c|c|c|c|c|c|}
\hline Reference & Trial or Patient Origin (Period) & $\begin{array}{l}\text { Cohort } \\
\text { Size }\end{array}$ & Age (y) & Type of ALL & Frequency del (Method) & EFS/DFS/RFS (p) & OS (p) & CIR (p) \\
\hline$[35]$ & $\begin{array}{l}\text { ICICLE (Indian adaption of } \\
\text { UKMRC2007 protocol) } \\
\quad(2015-2017)\end{array}$ & 83 & $1-12$ & $\mathrm{BCP}$ & $\begin{array}{l}\text { DKN2A } / \text { B del } 36 \% \\
\text { (MLPA) }\end{array}$ & $\begin{array}{c}\text { Univariate: } 28 \text { month-EFS } \\
\text { CDKN2A/B del } 42 \% \text { vs. wt } 90 \% \\
(p=0.0004) \\
\text { Multivariate: } \text { CDKN2A } / \text { B del } \\
\text { HR }=5.75(p=0.008)\end{array}$ & - & - \\
\hline$[47]$ & $\begin{array}{c}\text { St Jude Children's Research } \\
\text { Hospital } \\
(1993-2005) \\
\end{array}$ & 50 & $<18$ & T-ALL & $\begin{array}{l}\text { CDKN2A/B del 72\% } \\
\text { (SNP array) }\end{array}$ & - & - & - \\
\hline [24] & $\begin{array}{c}\text { UKALLXI ALL97-2003 } \\
(1986-2007)\end{array}$ & 266 & $<18$ & T-ALL & $\begin{array}{c}\text { CDKN2A/B del 50\% } \\
\text { (SNP array, CGHa, FISH) }\end{array}$ & - & - & - \\
\hline$[48]$ & $\begin{array}{l}\text { St Jude, the Children's Oncology } \\
\text { Group and AIEOP }\end{array}$ & $\begin{array}{l}\text { ETP } 42 \\
\text { Non-ETP } \\
64\end{array}$ & $<18$ & T-ALL & $\begin{array}{l}\text { ETP: CDKN2A del 25\% } \\
\text { Non-ETP: CDKN2A del 81\% } \\
\text { (SNPa) }\end{array}$ & - & & $\begin{array}{c}\text { Univariate. 5y-CDKN2A del } \\
24.2 \% \text { vs. wt } 35.8 \% \\
(p=0.2814)\end{array}$ \\
\hline [49] & $\begin{array}{c}\text { NOPHO } \\
\text { ALL-1981-1986-1992-2000-2008 } \\
(1983-2011) \\
\end{array}$ & 47 & $0-18$ & T-ALL & $\begin{array}{l}\text { CDKN2A del 72\% } \\
\text { CDKN2B del 62.5\% } \\
\text { (SNPa) }\end{array}$ & $\begin{array}{c}\text { Univariate: } 5 y-E F S \text { CDKN2A del } 0.48 \\
\text { vs. wt } 0.73(p=\text { ns) }\end{array}$ & $\begin{array}{c}\text { Univariate: } 5 y-C D K N 2 A \text { del } 0.52 \\
\text { vs. wt } 0.91(p=0.04)\end{array}$ & - \\
\hline$[50]$ & France and UK & 155 & $\begin{array}{l}111 \mathrm{c} . \\
44 \mathrm{a} .\end{array}$ & T-ALL & $\begin{array}{c}\text { CDKN2A del 78\% } \\
\text { (FISH, MLPA, CGHa, TDS) }\end{array}$ & - & - & - \\
\hline [43] & $\begin{array}{l}\text { PETHEMA } \\
(1996-2014) \\
\end{array}$ & 27 & $<18$ & T-ALL & $\begin{array}{l}\text { CDKN2A/B del } 70.4 \% \\
\text { (CGHa) }\end{array}$ & $\begin{array}{l}\text { Univariate: ns (outcome data } \\
\text { not shown) }\end{array}$ & $\begin{array}{l}\text { Univariate: ns (outcome data } \\
\text { not shown) }\end{array}$ & $\begin{array}{l}\text { Univariate: ns (outcome } \\
\text { data not shown) }\end{array}$ \\
\hline$[52]$ & $\begin{array}{l}\text { TPOG-ALL-93 } \\
(1995-2015)\end{array}$ & 102 & $<18$ & T-ALL & $\begin{array}{l}\text { CDKN2A del 63.3\%, } \\
\text { CDKN2B del 50\% } \\
\text { (MLPA) }\end{array}$ & - & $\begin{array}{l}\text { Univariate: ns (outcome data } \\
\text { not shown) }\end{array}$ & $\begin{array}{l}\text { Univariate: ns (outcome } \\
\text { data not shown) }\end{array}$ \\
\hline$[53]$ & $\begin{array}{l}\text { Brazilian Group Childhood } \\
\text { Leukemia 99 } \\
(2005-2017) \\
\end{array}$ & 341 & $<19$ & T-ALL & $\begin{array}{l}\text { CDKN2A/B del } 71.4 \% \\
\text { (MLPA) }\end{array}$ & - & $\begin{array}{l}\text { Univariate: } 5 \mathrm{y}-\mathrm{CDKN} 2 \mathrm{~A} / \mathrm{B} \text { del } \\
62.6 \% \text { vs. } \operatorname{wt} 62.5 \%(p=0.729)\end{array}$ & - \\
\hline$[54]$ & $\begin{array}{c}\text { Indian Childhood Collaborative } \\
\text { Leukemia (ICICLE) } \\
(2017-2018)\end{array}$ & 27 & $<18$ & T-ALL & $\begin{array}{l}\text { CDKN2A/B del 59.2\% } \\
\text { (digital MLPA) }\end{array}$ & - & $\begin{array}{l}\text { Univariate: ns (outcome data } \\
\text { not shown) }\end{array}$ & - \\
\hline
\end{tabular}

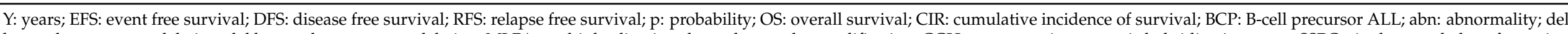

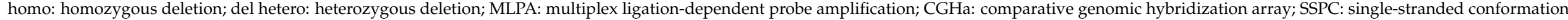

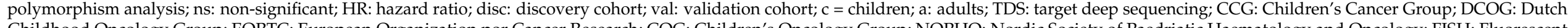

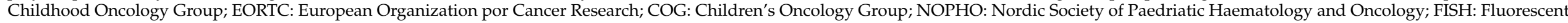

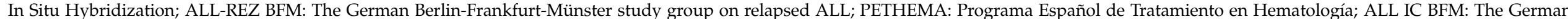

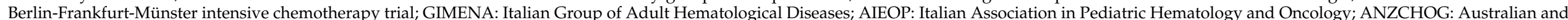
New Zealand Children's Haematology/Oncology; TPOG: Taiwan Pediatric Oncology Group. 
Table 2. Frequency and clinical impact of the $C D K N 2 A / B$ gene deletions in adult ALL.

\begin{tabular}{|c|c|c|c|c|c|c|c|c|}
\hline Reference & $\begin{array}{c}\text { Trial or Patient Origin } \\
\text { (Period) }\end{array}$ & Cohort Size & Age (y) & Type of ALL & Frequency del (Method) & EFS/DFS/RFS (p) & OS (p) & $\operatorname{CIR}(p)$ \\
\hline [55] & $\begin{array}{l}\text { MRC UKALLXII/ECOG } \\
\text { E2993 (1993-2004) }\end{array}$ & 796 & $15-65$ & $\mathrm{Ph}^{-} \mathrm{BCP}$ & $\begin{array}{c}\operatorname{del}(9 p) 9 \% \\
\text { (Karyotyping) }\end{array}$ & $\begin{array}{l}\text { Univariate: } 5 y-E F S \text { del }(9 p) 49 \% \\
\text { O/E } 0.73(p=0.043)\end{array}$ & $\begin{array}{c}\text { Univariate: } 5 \mathrm{y}-\mathrm{del}(9 \mathrm{p}) 58 \%, \mathrm{O} / \mathrm{R} \\
0.70(p=0.032)\end{array}$ & - \\
\hline [56] & $\begin{array}{c}\text { L-10 and Swedish ALL group } \\
\text { protocol } \\
(1986-2006)\end{array}$ & 240 & $17-78$ & $\mathrm{BCP}$ & $\begin{array}{c}9 \mathrm{p} \text { abn. } 7 \% \\
\text { (Karyotyping) }\end{array}$ & $\begin{array}{l}\text { Univariate: median EFS } 9 p \text { abn } 6 \\
\text { months vs. no } 9 p \text { abn } 2.5 \text { years, } \\
\qquad(p=0.0134)\end{array}$ & $\begin{array}{c}\text { Univariate: median OS 9p abn } \\
5 \text { months vs. no } 9 \mathrm{p} \text { abn }+ \text { no } \\
\text { HSCT } 5 \mathrm{y}(p=0.023) \\
\text { Multivariate: } 9 \mathrm{p} \text { abn } \mathrm{RR}=2.21 \\
(p=0.032)\end{array}$ & - \\
\hline [57] & $\begin{array}{l}\text { Japan Adult Leukemia Study } \\
\text { Group (JALSG) (2002-2005) }\end{array}$ & 80 & $15-64$ & $\mathrm{Ph}^{+} \mathrm{BCP}$ & $\begin{array}{c}9 \mathrm{p} \text { abn. } 10 \% \\
\text { (Karyotyping) }\end{array}$ & $\begin{array}{c}\text { Univariate: lower RFS, } \\
\qquad(p=0.005)\end{array}$ & - & - \\
\hline [58] & $\begin{array}{l}\text { UKALLXII/ECOG2993 } \\
(1993-2006)\end{array}$ & 454 & $15-65$ & $\mathrm{Ph}^{-} \mathrm{BCP}$ & $\begin{array}{l}\text { CDKN2A/B del 24\% } \\
\text { (MLPA, FISH) }\end{array}$ & $\begin{array}{c}\text { Univariate: } 5 \mathrm{y} \text {-EFS CDKN2A/B } \\
\text { del } 39 \% \text { HR }=1.20(p=0.247) \\
\text { 5y-EFS CDKN2A } / \text { B homo del vs. } \\
\text { mono del HR }=0.59(p=0.08)\end{array}$ & $\begin{array}{l}\text { Univariate: } 5 \mathrm{y}-\mathrm{CDKN} 2 \mathrm{~A} / \mathrm{B} \text { del } \\
42 \%, \mathrm{HR}=1.16(p=0.366)\end{array}$ & - \\
\hline [59] & $\begin{array}{l}\text { PETHEMA AR93-03, OLD07, } \\
\text { RI96-RI08 and Ph08 } \\
\text { (1993-2013) }\end{array}$ & 152 & $15-74$ & ВСР & $\begin{array}{l}\text { CDKN2A/B del } 42 \% \\
\text { (MLPA) }\end{array}$ & - & $\begin{array}{c}\text { Univariate: } 5 \mathrm{y}-\mathrm{CDKN} 2 \mathrm{~A} / \mathrm{B} \text { del } \\
25 \% \text { vs. wt } 57 \%(p=0.001) \\
5 \mathrm{y}-\mathrm{Ph}^{+} \text {CDKN2A } \mathrm{CD} \text { del } 14 \% \text { vs. } \\
54 \%(p=0.025) \\
\text { Multivariate: CDKN2A/B del } \\
\text { HR }=2.545(p<0.001)\end{array}$ & $\begin{array}{c}\text { Univariate: } \\
\text { CDKN2A/B del } 54 \% \text { vs. } \\
\text { wt } 41 \%(p=0.063) ; \\
5 y-\mathrm{Ph}^{+} \mathrm{CDKN} 2 \mathrm{~A} / \mathrm{B} \text { del } \\
100 \% \text { vs. } 43 \% \\
(p=0.071)\end{array}$ \\
\hline [60] & $\begin{array}{l}\text { Chinese Han-South Medical } \\
\text { University } \\
(2008-2013)\end{array}$ & 215 & $15-60$ & $\mathrm{BCP}$ & $\begin{array}{l}\text { Diagnosis: CDKN2A/B del 28\% } \\
\text { 1st relapse: CDKN2A/B del 45\% } \\
\text { (FISH) }\end{array}$ & $\begin{array}{c}\text { Univariate diagnosis: EFS } \\
\text { CDKN2A/B del 12 vs. wt } 24 \\
\text { months ( } p<0.0001) \\
\text { Univariate } 1 \text { st relapse: EFS } \\
\text { CDKN2A/B del } 5 \text { vs. wt } 16 \\
\text { months }(p=0.004)\end{array}$ & $\begin{array}{c}\text { Univariate diagnosis: } \\
\text { CDKN2A/B del 19 vs. wt } 30 \\
\text { months }(p<0.0001) \\
\text { Univariate } 1 \text { st relapse: } \\
\text { CDKN2A/B del 8 vs. wt } 18 \\
\text { months }(p=0.001)\end{array}$ & $\begin{array}{l}\text { Univariate diagnosis: } \\
\text { 2y-CDKN2A/B del 59\% } \\
\text { vs. wt } 36 \%(p=0.002)\end{array}$ \\
\hline [43] & $\begin{array}{l}\text { PETHEMA AR93-03-11, RI96, } \\
\text { OLD07, Ph00-08 } \\
\text { (1996-2014) }\end{array}$ & 100 & $18-84$ & $\mathrm{BCP}$ & $\begin{array}{l}\text { CDKN2A/B del 47\% } \\
\text { (CGHa) }\end{array}$ & $\begin{array}{l}\text { Univariate: } \mathrm{ns} \\
\text { (outcome data not shown) }\end{array}$ & $\begin{array}{l}\text { Univariate: } \mathrm{ns} \\
\text { (outcome data not shown) }\end{array}$ & $\begin{array}{l}\text { Univariate: ns } \\
\text { (outcome data not } \\
\text { shown) }\end{array}$ \\
\hline [61] & $\begin{array}{c}\text { Chinese Han-South Medical } \\
\text { University } \\
(2008-2014)\end{array}$ & 135 & $18-65$ & $\mathrm{Ph}^{+} \mathrm{BCP}$ & $\begin{array}{l}\text { CDKN2A/B del 33\% } \\
\text { (FISH) }\end{array}$ & $\begin{array}{l}\text { Univariate: } 2 \mathrm{y} \text {-DFS CDKN2A/B } \\
\text { del } 23 \% \text { vs. wt } 35 \%(p=0.005)\end{array}$ & $\begin{array}{l}\text { Univariate: } 2 \mathrm{y}-\mathrm{CDKN} 2 \mathrm{~A} / \mathrm{B} \text { del } \\
51 \% \text { vs. wt } 65 \%(p=0.004)\end{array}$ & $\begin{array}{c}\text { Univariate: } \\
\text { 2y-CDKN2A/B del 59\% } \\
\text { vs. wt } 35 \%(p=0.008)\end{array}$ \\
\hline
\end{tabular}


Table 2. Cont.

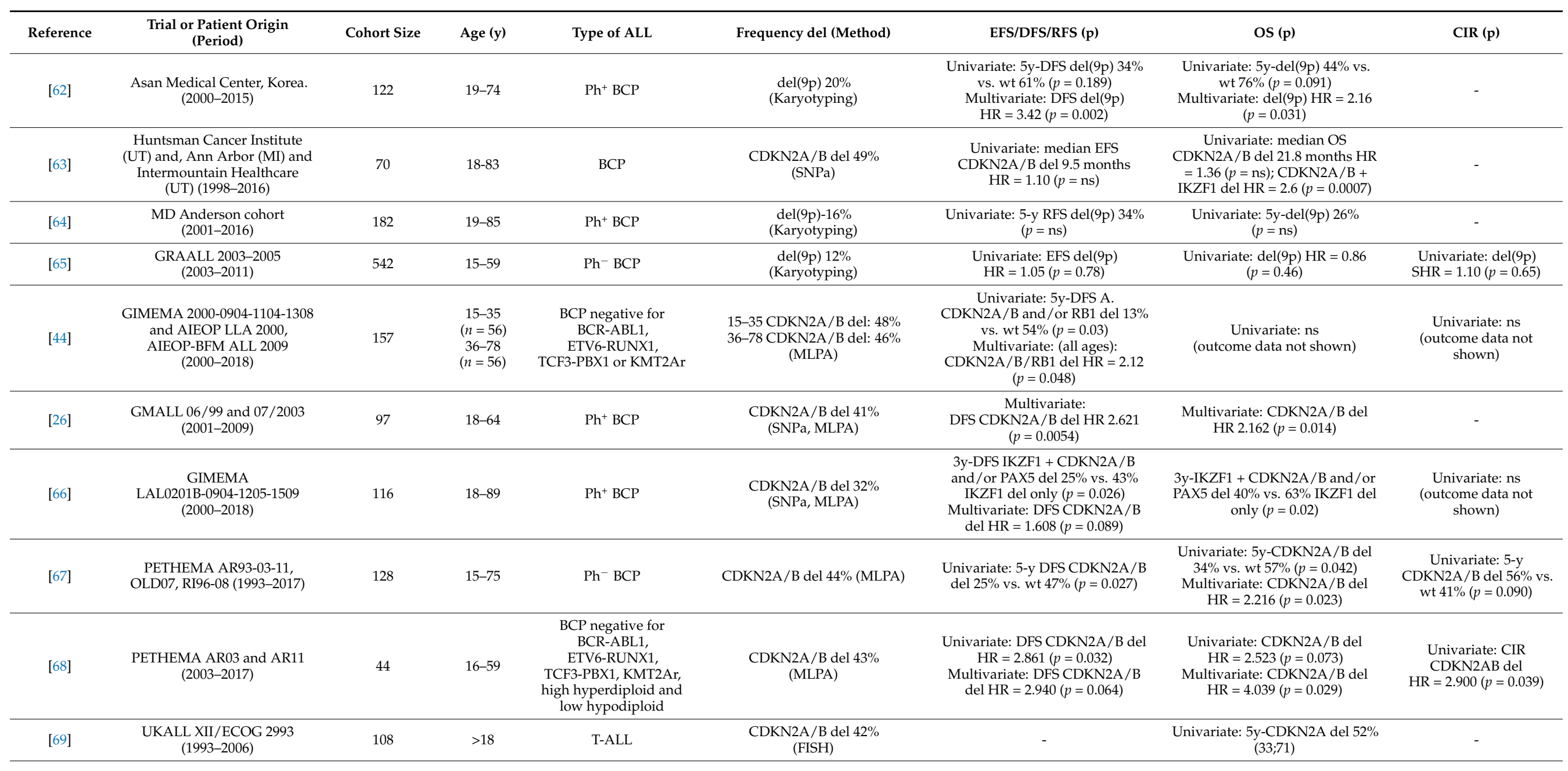


Table 2. Cont.

\begin{tabular}{|c|c|c|c|c|c|c|c|c|}
\hline Reference & $\begin{array}{l}\text { Trial or Patient Origin } \\
\text { (Period) }\end{array}$ & Cohort Size & Age (y) & Type of ALL & Frequency del (Method) & EFS/DFS/RFS (p) & OS (p) & CIR (p) \\
\hline [70] & $\begin{array}{l}\text { GMALL } 07 / 2003 \text { and GMALL } \\
\text { Elderly } 01 / 2003\end{array}$ & 90 & $18-88$ & T-ALL & $\begin{array}{l}\text { CDKN2A/B del 43\% } \\
\text { (FISH) }\end{array}$ & - & $\begin{array}{l}\text { Univariate: } 2 \mathrm{y} \text {-CDKN2A/B del } \\
77.2 \% \text { vs. wt } 47.2 \%(p=0.076)\end{array}$ & - \\
\hline [71] & UKALL XII/ECOG 2993 & 53 & $>18$ & T-ALL & $\begin{array}{l}\text { CDKN2A/B del 41\% } \\
\text { (CGHa) }\end{array}$ & - & $\begin{array}{c}\text { Univariate: } 5 y-C D K N 2 A / B \text { del } \\
\text { homo } 71 \% \text { vs. del hetero } 38 \% \\
(p=0.0119)\end{array}$ & - \\
\hline [72] & $\begin{array}{c}\text { Lithuania } \\
(2007-2013) \\
\end{array}$ & 25 & $18-64$ & T-ALL & $\begin{array}{l}\text { CDKN2A/B del 28\% } \\
\text { (SNPa) }\end{array}$ & $\begin{array}{c}\text { Univariate: ns } \\
\text { (outcome data not shown) }\end{array}$ & $\begin{array}{c}\text { Univariate: } \mathrm{ns} \\
\text { (outcome data not shown) }\end{array}$ & - \\
\hline [43] & $\begin{array}{l}\text { PETHEMA AR93-03, AR11, } \\
\text { RI96, OLD07, Ph00-08 } \\
\text { (1996-2014) }\end{array}$ & 23 & $18-84$ & T-ALL & $\begin{array}{l}\text { CDKN2A/B del } 8.7 \% \\
\text { (CGHa) }\end{array}$ & $\begin{array}{l}\text { Univariate: ns } \\
\text { (outcome data not shown) }\end{array}$ & $\begin{array}{c}\text { Univariate: ns } \\
\text { (outcome data not shown) }\end{array}$ & $\begin{array}{l}\text { Univariate: } \mathrm{ns} \\
\text { (outcome data not } \\
\text { shown) }\end{array}$ \\
\hline [73] & $\begin{array}{l}\text { Institute of Hematology and } \\
\text { Blood Diseases Hospital } \\
\text { (China) (2009-2015) }\end{array}$ & 18 & $14-61$ & T-ALL & $\begin{array}{l}\text { CDKN2A del 50\% } \\
\text { CDKN2B del 33.3\% } \\
\text { (MLPA) }\end{array}$ & $\begin{array}{c}\text { Univariate: } \mathrm{ns} \\
\text { (outcome data not shown) }\end{array}$ & $\begin{array}{c}\text { Univariate: } \mathrm{ns} \\
\text { (outcome data not shown) }\end{array}$ & $\begin{array}{l}\text { Univariate: } \mathrm{ns} \\
\text { (outcome data not } \\
\text { shown) }\end{array}$ \\
\hline [74] & $\begin{array}{l}\text { PETHEMA HR-2003-11 } \\
\text { (2003-2017) }\end{array}$ & 62 & $16-72$ & T-ALL & $\begin{array}{l}\text { CDKN2A del } 50 \% \\
\text { CDKN2B del } 47 \% \\
\text { (qPCR) }\end{array}$ & - & $\begin{array}{c}\text { Univariate: } 3 y- \\
\text { CDKN2A/B del 75\% vs. wt } 36 \% \\
(p=0.05)\end{array}$ & - \\
\hline [75] & $\begin{array}{c}\text { Seoul St. Mary's Hospital } \\
(2004-2015)\end{array}$ & 102 & $2-77$ & T-ALL & $\begin{array}{l}\text { CDKN2A/B del } 45.1 \% \\
\text { (MLPA) }\end{array}$ & - & $\begin{array}{c}\text { Univariate: ns (outcome data not } \\
\text { shown) }\end{array}$ & - \\
\hline
\end{tabular}

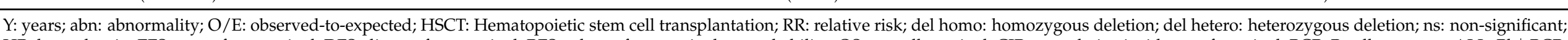

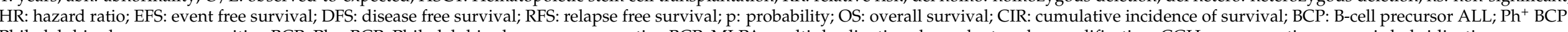

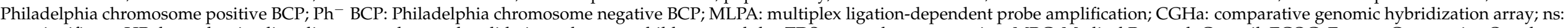

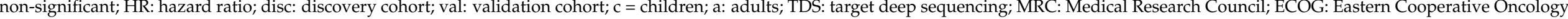
Group; UT: Utah; MI: Michigan; GRAALL: Group for Research on Adult Acute Lymphoblastic Leukemia trial; German Multicenter ALL: German Multicenter ALL trial. 


\subsection{3. del(9p21.3) in T-ALL}

$C D K N 2 A / B$ gene deletions are also the commonest alteration in T-ALL. The first study that reported this finding, based on Southern blot analyses, showed $C D K N 2 A / B$ deletions in $70 \%$ of T-ALL cases, where they occur as homozygous deletions [81]. Despite the technical limitation, it was evident that this alteration plays a basic role in T-ALL, for which reason it has been studied over the years in pediatric and adult cohorts using different techniques.

Focusing on pediatric cohorts and using different techniques (SNP arrays, multiplex ligation-dependent probe amplification (MLPA) and digital MLPA), the frequency of $C D K N 2 A / B$ deletions has been found to range from $50 \%$ to $81 \%$ (Table 1 ). Some studies of adults, who account for $25 \%$ of ALL cases, have used fluorescent in situ hybridization (FISH) to identify $C D K N 2 A / B$ deletions (Table 2). Globally, these studies have shown a frequency of $C D K N 2 A / B$ deletions of around $42 \%$. More recently, the use of SNPs to study CDKN2A/B deletions has yielded frequencies between $28 \%$ and $50 \%$ (Table 2). Age stratification in ALL patients gives rise to a third group of patients of intermediate age, between children and adults, known as AYAs (adolescents and young adults). This group often presents unique specific genetic alterations [21]. The frequency of $C D K N 2 A / B$ deletions in this age-related group accounts for $47 \%$ [21,82].

With respect to homozygosity, most deletions in this gene are present in both alleles (approximately 70\% of cases), independently of the cohort age (Tables 1 and 2). This observation is at odds with a study hypothesizing that biallelic deletions are more frequent in adults than in pediatric cases, since conversion of monoallelic into biallelic deletion could require additional time [83].

Similar to what occurs in BCP-ALL, T-ALL also shows a specific association of $C D K N 2 A / B$ deletions with a particular subgroup of patients, specifically with the nonimmature T-ALL leukemias. Since the initial estimates of $27 \%$ and $77 \%$ of $C D K N 2 A / B$ deletions in the early T-cell precursor ALL (ETP-ALL) and non-ETP patients $(p=0.0036)$ [84], respectively, several studies have produced results concordant with this association. Therefore, the $C D K N 2 A / B$ deletion is a common alteration in cortical/mature T-ALL subtypes characterized by the overexpression of TLX1 and TLX3 [48,50,53,71,74,75], whereas the frequency in immature subtypes is significantly lower $[48,84]$. T-ALL subtypes characterized by the presence of $C D K N 2 A / B$ deletions also show a high frequency of the NOTCH1 mutation, although this association is not statistically significant $[85,86]$. However, there is a subgroup, of 1-6\% of adult and childhood T-ALL that is characterized by the presence of an MYC translocation that is associated with high rates of $C D K N 2 A / B$ deletions (75\%). The genetic subgroup is also associated with PTEN inactivation and the absence of NOTCH1 and FBXW7 mutations $[87,88]$.

\subsection{Epigenetic Modifications at the CDKN2A/B Gene Promoter (T-ALL and BCP-ALL)}

Alterations in the methylation pattern of the promoter of the CDKN2A/B genes have also been described in ALL, although they are much less frequent than deletions. A review of the literature regarding this topic indicates a greater degree of promoter hypermethylation of these genes in T-ALL than in BCP-ALL (Tables 3 and 4).

Globally, if we consider the $\mathrm{B}$ and $\mathrm{T}$ subtypes in the adult and pediatric cohorts together we find that the range of methylation is between $10 \%$ and $47 \%$ for the CDKN2B gene promoter and between $0 \%$ and $41 \%$ for the CDKN2A promoter (Tables 3 and 4 ). These differences do not vary with age $(25 \%$ pediatric vs. $31 \%$ adult cases for the CDKN2B gene promoter; $12 \%$ pediatric vs. $3 \%$ adult cases for the CDKN2A gene promoter) [99]. In BCP-ALL, CDKN2B hypermethylation is more frequent than CDKN2A hypermethylation, and methylation of both genes may also increase with age (Table 4). In T-ALL patients, we observe that the percentage of promoter methylation in the CDKN2B and CDKN2A genes ranges between $46 \%$ and $68 \%$, and between $0 \%$ and $12 \%$, respectively, in pediatric cohorts (Table 3). Little information is available for adult T-ALL cohorts and shows that the percentage of CDKN2B gene promoter methylation varies from $16 \%$ to $49 \%$, and is $1 \%$ for 
the CDKN2A promoter (Table 4). In T-ALL, the CDKN2B methylation status is associated with an immature immunophenotype [70] and with ETP-ALL features [75].

\subsection{Germline Predisposition Variants in the CDKN2A/B Gene Cluster (T-ALL and BCP-ALL)}

Germline mutations in both genes, but most importantly in $C D K N 2 A$, have been identified by SNPa. These inherited variants are associated with an increased risk of suffering ALL in pediatric case-control studies [100], raising the question about whether these variants may also occur in adults, or if they are more critical at earlier stages of development. Conversely, SNPs that protect against BCP-ALL development have also been reported [101]. As well as CDKN2A coding region (exon) germline mutations, SNPs predisposing to BCP-ALL have been observed in introns [100] and in non-coding regions, such as its promoter, that are important for regulating $C D K N 2 A / B$ gene expression [101].

A critical aspect of these variants is their preferentially familial inheritance. Once inherited, germline pathogenic variants have a clear preferential expression compared with the non-pathological allele and, importantly, are not affected by the recurrent $C D K N 2 A / B$ deletions [102,103], suggesting that the two alterations, one in each allele, are both needed to fully disrupt the normal cellular function of P16 and P15, as has been shown for RB1 and TP53 in other cancer models [104]. No association has so far been reported among any particular ALL genetic subtype and $C D K N 2 A / B$ polymorphisms or other polymorphisms affecting genes essential to ALL development. This may reflect the fact that germline ALL-predisposing SNPs, including those involving CDKN2A/B, IKZF1 and PAX5, sustain a pre-leukemic environment favoring the appearance of primary genetic lesions that lead to leukemia, instead of causing the appearance of a specific rearrangement/genetic primary abnormality, at least when referring to $C D K N 2 A / B$-related germline variants [105]. However, a CDKN2A SNP specifically related to Down syndrome ALL patients has recently been reported [106]. 
Table 3. Frequency and impact of the $C D K N 2 A / B$ gene promoter methylation status in childhood ALL.

\begin{tabular}{|c|c|c|c|c|c|c|c|c|}
\hline \multirow{2}{*}{ Reference } & \multirow{2}{*}{ Type of ALL } & \multirow{2}{*}{ Cohort Size } & \multirow{2}{*}{ Age (y) } & \multirow{2}{*}{ Technique } & \multicolumn{2}{|c|}{ Frequency of Methylation } & \multicolumn{2}{|r|}{ Prognosis } \\
\hline & & & & & CDKN2A (n) & CDKN2B (n) & CDKN2A & CDKN2B \\
\hline \multirow{2}{*}{ [89] } & $\mathrm{BCP}$ & 23 & \multirow{2}{*}{$<18$} & \multirow{2}{*}{ MS-PCR } & $0 \%(23)$ & $48 \%(23)$ & & - \\
\hline & T-ALL & 12 & & & $0 \%(12)$ & $50 \%(12)$ & & - \\
\hline [90] & T-ALL & 45 & $<18$ & MS-PCR & $11.7 \%(17)$ & $68 \%(25)$ & & - \\
\hline \multirow{2}{*}{ [91] } & $\mathrm{BCP}$ & \multirow{2}{*}{36} & \multirow{2}{*}{$<18$} & \multirow{2}{*}{ MS-PCR } & \multirow{2}{*}{-} & $13 \%(23)$ & \multirow{2}{*}{\multicolumn{2}{|c|}{ - }} \\
\hline & T-ALL & & & & & $46.2(13)$ & & \\
\hline [92] & $\begin{array}{l}\text { BCP and } \\
\text { T-ALL }\end{array}$ & 95 & $<18$ & MS-PCR & $4 \%(95)$ & $25 \%(95) *$ & \multicolumn{2}{|r|}{ Non-significant } \\
\hline [19] & $\mathrm{BCP}$ & 333 & $<18$ & MS-MLPA & $3.9 \%(333)$ & $87 \%(333)$ & Non-significant & Univariate: trend to poor OS \\
\hline \multirow{2}{*}{ [93] } & $\mathrm{BCP}$ & \multirow{2}{*}{93} & \multirow{2}{*}{$1-13$} & \multirow{2}{*}{ MS-PCR } & - & $57 \%(21)$ & \multirow{2}{*}{-} & \multirow{2}{*}{$\begin{array}{c}\text { Univariate: EFS-8y hyper.71\% vs. hypo } 91 \%(p=0.02) \text {; rate of relapse } \\
\text { hyper } 28 \% \text { vs. hypo } 9.3 \%(p=0.02)\end{array}$} \\
\hline & T-ALL & & & & - & $38 \%(72)$ & & \\
\hline
\end{tabular}

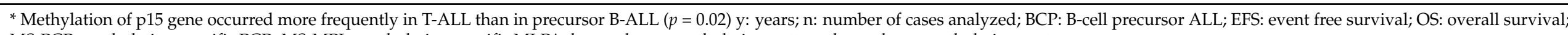
MS-PCR: methylation specific PCR; MS-MPL: methylation specific MLPA; hyper: hyper methylation pattern; hypo: hypo methylation pattern. 
Table 4. Frequency and impact of the $C D K N 2 A / B$ gene promoter methylation status in adult ALL.

\begin{tabular}{|c|c|c|c|c|c|c|c|c|}
\hline \multirow{2}{*}{ Reference } & \multirow{2}{*}{$\begin{array}{l}\text { Type of } \\
\text { ALL }\end{array}$} & \multirow{2}{*}{$\begin{array}{l}\text { Cohort } \\
\text { Size }\end{array}$} & \multirow{2}{*}{ Age (y) } & \multirow{2}{*}{ Technique } & \multicolumn{2}{|c|}{ Frequency of Methylation } & \multicolumn{2}{|r|}{ Prognosis } \\
\hline & & & & & CDKN2A (n) & CDKN2B (n) & CDKN2A & CDKN2B \\
\hline \multirow{2}{*}{ [94] } & $\mathrm{BCP}$ & 41 & \multirow{2}{*}{$>18$} & \multirow{2}{*}{ MS-PCR } & $12.5 \%(41)$ & $2.4 \%(41)$ & \multirow{2}{*}{-} & $\begin{array}{l}\text { Univariate: } 5 y-O S \text { methy } 12 \% \text { vs. un-methy } 36 \% \\
(p=0.84) ; 5 y-D F S \text { methy } 7 \% \text { vs. un-methy } 19 \%\end{array}$ \\
\hline & T-ALL & 8 & & & $62.5 \%(8)$ & $39 \%(8)$ & & $(p=0.98)$ \\
\hline [95] & $\mathrm{BCP}$ & 70 & $>18$ & MS-PCR & $23 \%(70)$ & $37 \%(70)$ & - & $\begin{array}{l}\text { Multivariate: normal CDKN2B was a favourable } \\
\text { prognostic factor for longer DFS ( } p=0.0001)\end{array}$ \\
\hline \multirow[t]{2}{*}{ [96] } & $\mathrm{BCP}$ & \multirow[t]{2}{*}{80} & \multirow[t]{2}{*}{$>18$} & \multirow[t]{2}{*}{ MS-PCR } & \multirow[t]{2}{*}{$2.5 \%(80)$} & \multirow[t]{2}{*}{$22.5 \%(71)$} & $\begin{array}{c}\text { Univariate: } \mathrm{Ph}^{-}(n=57) \\
\text { 5y-OS methy } 50 \% \text { vs. } \\
\text { un-methy } 42 \% \text { ( } p=0.8)\end{array}$ & $\begin{array}{c}\text { Univariate: } \mathrm{Ph}^{-}(n=57) 5 \mathrm{y}-\mathrm{OS} \text { methy } 26 \% \text { vs. } \\
\text { un-methy } 46 \%(p=0.09)\end{array}$ \\
\hline & T-ALL & & & & & & Non-significant & Non-significant \\
\hline [97] & $\begin{array}{l}\text { BCP and } \\
\text { T-ALL }\end{array}$ & 64 & $16-78$ & MS-PCR & - & $25 \%(64)$ & - & Non-significant \\
\hline [98] & $\begin{array}{l}\mathrm{Ph}^{-} \text {and } \\
\text { MLL-BCP }\end{array}$ & 199 & $15-83$ & $\begin{array}{l}\text { Real Time } \\
\text { bisulfite } \\
\text { PCR }\end{array}$ & - & $17.4 \%(189)$ & - & Non-significant \\
\hline [75] & T-ALL & 102 & $2-77$ & pyrosequencing & $3.8 \%(93)$ & $50.6 \%(93)^{* *}$ & - & $\begin{array}{c}\text { Univariate: } 3 y \text {-EFS high methy } 35.9 \% \text { vs. low } \\
\text { methy } 59.1 \%(p=0.042) \\
\text { Multivariate: } C D K N 2 B \text { biallelic deletion or } \\
\text { high methylation } \\
\text { HR }=6.358(p=0.012)\end{array}$ \\
\hline
\end{tabular}

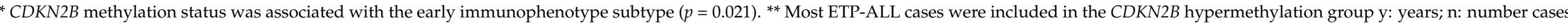

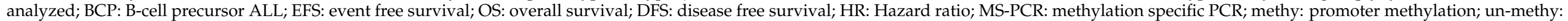

un-methylated promoter. 


\section{Clinical Impact of $C D K N 2 A / B$ Alterations in ALL}

Given the range of frequencies of the deletion in the different ALL subtypes (B-ALL and T-ALL), it is reasonable to expect to find some differences in the impact of these changes in the clinical environment, so the results obtained will not necessarily be concordant with those obtained from analyzing mixed ALL cohorts. Similarly, the prognostic significance of $C D K N 2 A / B$ deletions should be addressed through a consideration of the influence of age on patient outcome and the method employed to analyze the frequency of the alteration. In addition, the size of the study cohort can be an impediment to arriving at a more accurate prognostic value, especially if we want to estimate it for $C D K N 2 A / B$ deletions within a particular cytogenetic subtype, or the combination of $C D K N 2 A / B$ losses with other molecular alterations. Moreover, modern ALL treatment protocols include minimal residual disease (MRD) measurement for stratifying patients during treatment $[107,108]$. Therefore, the prognostic impact of genetic markers should be also assessed in combination with MRD values.

\subsection{Clinical Implications of Deletions in BCP-ALL}

It seems that the treatment optimization for children applied in the more modern MRD-oriented protocols may overcome the supposed poor outcome related to $C D K N 2 A / B$ deletions. However, some evidence suggests that homozygous $C D K N 2 A$ deletions may be specifically more damaging, even though patients are treated according to these modern protocols [19,35], especially in children without high-risk features [45] and in patients with early relapses [42]. Conversely, other authors have identified poorer-prognosis patients with heterozygous deletions (Table 1) [35]. There is very little information about the prognosis of these deletions within the AYA group in large series focusing on BCP-ALL. However, younger age may counterbalance the absence of $C D K N 2 A / B$, since there is no strong evidence of a link between this genetic marker and poor prognosis in this group of patients [44].

For adults, the prognostic impact of $C D K N 2 A / B$ genes deletions is more evident in $\mathrm{Ph}^{+}$ than in $\mathrm{Ph}^{-} \mathrm{BCP}$-ALL patients. The paper by the German ALLcooperative group argues strongly that $C D K N 2 A / B$ deletions are a reliable prognostic marker of poor prognosis in $\mathrm{Ph}^{+}$patients treated with chemotherapy plus imatinib and allogeneic stem cell transplantation (allo-SCT) (Table 2) [26]. Results from previous studies were also in line with this observation $[18,61,62]$. The prognostic value of $C D K N 2 A / B$ deletions is less clear in the case of $\mathrm{Ph}^{-} \mathrm{BCP}-\mathrm{ALL}$, probably because the genetic background of $\mathrm{Ph}^{-}$is much more heterogeneous than that of $\mathrm{Ph}^{+}$. On one hand, the UK group on ALL study suggests that $C D K N 2 A / B$ losses have no impact on outcome [58], while on the other hand, analysis of smaller series of $\mathrm{Ph}^{-}$patients suggests that $C D K N 2 A / B$ deletions could be a marker of poor outcome, especially concomitantly with IKZF1 [63,68,80] or RB1 deletions [44], as has been shown in pediatric cohorts [109]. Frequent codeletion of $C D K N 2 A / B$ and IKZF1 (in addition to RB1 deletion and JAK/STAT pathway mutations) has also been found in Ph-like patients, a new genetic subgroup recently identified by gene expression profiling (GEP) [110] and initially including the $\mathrm{Ph}^{-}$group, suggesting that the worse outcome of this codeletion in $\mathrm{Ph}^{-}$patients could be due to the negative impact of these deletions on Ph-like patients. Consistent with this, we have recently shown that $C D K N 2 A / B$ deletions could also be a marker of poor prognosis in Ph-like patients (Table 2) [68].

Finally, very few studies have pointed out the importance of $C D K N 2 A / B$ losses as a worse prognosis marker in MRD-oriented trials. We have shown that CDKN2A/B losses might be a marker of poor outcome independently of MRD in adult $\mathrm{Ph}^{-}$patients treated according to the PETHEMA protocols [80], as has also been shown in some pediatric studies $[19,35]$.

\subsection{Clinical Implications of Deletions in T-ALL}

Most studies of pediatric cohorts show that $C D K N 2 A / B$ deletions have no prognostic relevance in T-ALL (Table 1), with the exception of the NOPHO (Nordic Society of Paedri- 
atic Haematology and Oncology) cohort study, in which deletions in the CDKN2A/B gene cluster were associated with lower OS. However, no effects on event-free survival (EFS) or relapse-free survival (RFS) were observed [111]. In contrast, many studies have shown that, in terms of OS, the presence of deletions in CDKN2A/B genes confers a better outcome, or a trend towards one, in adult T-ALL patients (Table 2). The good outcome observed in adult T-ALL patients is consistent with the fact that deletions in CDKN2A/B are more frequent in cortical/mature T-ALL subgroups, which are characterized by their better outcome when compared with more immature subtypes $[70,71,74]$. The exception to that result is the UKALL cohort study, in which the OS was identical in patients with and without deletions [69]. It is of note that the difference in outcome revealed by the various studies was not related to the gene dosage (homozygous vs. heterozygous deletions) (Table 2).

Finally, if we consider the MRD values when the analysis of the impact of $C D K N 2 A / B$ deletions is assessed we note that only the ALL Spanish Cooperative Group (PETHEMA) has analyzed this relationship. We showed that patients with biallelic or monoallelic deletions of $C D K N 2 A$ have stronger MRD responses (MRD levels $\leq 0.1 \%$ at the end of induction treatment) than those with normal copy number values. Despite these findings, when independent prognosis factors for OS were sought in multivariate analyses, MRD after induction therapy proved to be the only variable with independent predictive value [74].

\subsection{Clinical Impact of Epigenetic Modifications (BCP-ALL and T-ALL)}

Unlike deletion, the prognostic impact of $C D K N 2 A / B$ promoter hypermethylation, and, to an even lesser extent, gene body hypermethylation and hydroxymethylation, has not been thoroughly analyzed in BCP-ALL because of the greater extent of promoter hypermethylation in T-ALL (Tables 3 and 4). Accordingly, methylation of these genes does not seem to be very critical for BCP-ALL progression, and if so, this could be attributable to the combination of methylation and the loss of $C D K N 2 B$ in the other allele $[19,95]$. However, it is surprising that only one study has explored the outcome of $C D K N 2 B$ inactivation by methylation or deletion in T-ALL patients [75], showing that patients with either biallelic deletion or a high level of methylation exhibit lower 3-year EFS and OS than those with monoallelic deletion or low levels of methylation (Table 4).

Considering ALL globally (B-ALL and T-ALL subtypes), very few studies have analyzed the impact of methylation status in $C D K N 2 A / B$ promoters. A study of childhood ALL showed that patients with a methylated $C D K N 2 B$ promoter have a lower EFS rate and a higher incidence of relapse and mortality than those without methylation (Table 3) [93]. Conversely, in the only study of an adult ALL cohort, neither CDKN2B nor CDKN2A methylation affected the OS of patients (Table 4) [96].

\section{Functional Implications of the $C D K N 2 A / B$ Locus in ALL}

INK4a, as a type of INK4 protein, binds to CDK4 and CDK6 and inhibits their kinase activity, thereby affecting RB function. The expression of $C D K N 2 A$, or of other family members, produces RB hypophosphorylation, which in turn leads to $E 2 F$ repression and growth arrest. Absence of INK4a triggers constitutive RB phosphorylation and thereby E2F activation and growth progression [112]. However, ARF can also induce cell-cycle arrest, even in cells with active cyclin D, suggesting that RB-independent ARF signaling occurs that also controls cell-cycle arrest [4]. Studies done in $\mathrm{Arf}^{+/+}$or $\mathrm{Arf}^{+/-}$mouse embryonic fibroblasts (MEFs) showed that Arf and p53 form part of a common genetic pathway $[113,114]$, revealing the relationship between these two tumors suppresses genes. Arf can inhibit the transformation of MEFs in the presence of MDM2 inhibitor (120) by directly binding to the MDM2 protein and inhibiting the ubiquitination of TP53, thereby stabilizing this tumorsuppressor protein [115-118]. Therefore, deletion in the CDKN2A/B locus simultaneously compromises the function of both RB and p53 tumor suppressors genes.

The first in vivo evidence that p16-INK4a (INK4a) and p14-ARF (ARF) can protect cells from acquiring oncogenic properties came from Ink4-null mice in which the expression of both genes (Cdkn2a and Arf) was eliminated [119]. These mice displayed, among others, 
features consistent with abnormal extramedullary hematopoiesis, suggesting that Ink4a and Arf normally regulate the proliferation of some hematopoietic progenitor cells [119]. However, this model was unable to resolve the oncogenic contribution of the individual proteins. The specific contribution of the ARF protein was assessed later in a single Arf $\mathrm{KO}$. Mice lacking Arf expression were highly prone to spontaneous and carcinogen-induced tumors, including $\mathrm{T}$ cell lymphomas [113]. The mouse phenotype was much closer to that of double-null KO mice [119] than Cdkn2a-null mice [120,121], suggesting that the oncogenic properties associated with this locus were manly linked to the absence of the ARF gene.

\subsection{Role of INK4a/ARF Proteins in Leukemogenesis}

It has been suggested that the expression of $C D K N 2 A / B$ genes varies during hematopoiesis [122], implying a possible role for these genes in leukemogenesis. The underlying idea is that $C D K N 2 A / B$ genes would be epigenetically silenced by BMI1-containing polycomb repression complexes (PRCs) to facilitate both hematopoietic stem cell (HSC) and leukemic initiating cell (LICs) self-renewal. Absence of BMI1 would compromise the proliferative potential of leukemic stem and progenitor cells because they eventually undergo proliferation arrest and show signs of differentiation and apoptosis, leading to transplant failure of the leukemia. Defects resulting from BMI1 deletion can be partially rescued by co-deletion of $C D K N 2 A / B$ genes, demonstrating the importance of maintaining silencing of this locus in early developmental stages of hematopoiesis and leukemogenesis [123-127].

With the aim to establish a functional relationship between constitutive NOTCH1 signaling and $A R F$ deletion in T-ALL, the hypothesis developed above was tested in NOTCH1-dependent T-ALL leukemias generated in mouse models [128]. Transformation of $A r f^{+/+}$or $A r f^{-/-}$bone marrow precursor cells or thymocyte-derived cells with the constitutively active form of NOTCH1 $\left(\mathrm{ICN}^{+}\right)$showed a bivalent H3k27me3 and H3k4me3 methylation pattern present throughout the locus in the $\mathrm{Ar}{ }^{+/+}$and $\mathrm{Arf}{ }^{-/-}$ marrow-derived, and in the $A r f^{-/-}$thymocyte-derived cells. These modifications denote gene silencing [129] and detect binding of repressive Prc2 components (Ezh2 and Eed), which are known to participate in the repression of the Cdkn2a/b genes [123-129]. Promoters bearing bivalent $\mathrm{H} 3 \mathrm{~K} 27 \mathrm{Me} 3$ and $\mathrm{H} 3 \mathrm{~K} 4 \mathrm{Me} 3$ marks are thought to represent loci that are "poised" to begin transcription in response to appropriate stimuli. Arf ${ }^{--}$cultured thymocytes transduced with ICN1+ rapidly induced fatal T-ALL when infused into healthy syngeneic mice. In a similar way but with a long onset, ICN1+ bone marrow-derived progenitors ultimately gave rise to T-ALLs that were clinically and pathologically identical to those induced by thymocytes. In contrast, $A r f^{+/+} \mathrm{ICN1}^{+}$-transduced thymocytes expressed Arf protein and were less leukemogenic (135). This implies that in more mature T-cell progenitors the epigenetic remodeling of the Arf promoter is possible and, therefore, an additional genetic event in the $C D K N 2 A / B$ gene locus, such as deletion, is needed to fully transform mature ICN1 ${ }^{+}$T-cell precursors $[128,130]$.

The same hypothesis was tested in BCP-ALL. Expression of the BCR-ABL oncogene is the founding genetic lesion and the cytogenetic hallmark of both $\mathrm{Ph}^{+} \mathrm{ALL}$ and chronic myeloid leukemia (CML) [131,132]. However, CDKN2A/B deletions do not occur in CML; probably because the leukemia arises from HSC-like progenitors [123,125], in which the $C D K N 2 A / B$ locus is epigenetically silenced and "poised" to respond to an abnormally higher and sustained threshold of hyperproliferative signals [122]. Conversely, in $\mathrm{Ph}^{+} \mathrm{ALL}$, the leukemia-initiating cells appear to be committed lymphoid progenitors [133]. In that sense, mice engraftment of B-cell progenitors including the pro-B cells transduced with BCR-ABL1 oncogene showed that thus immature B-cell progenitors efficiently initiate $\mathrm{Ph}^{+}$ B-ALL, but pre-B cells did not do [134]. The reason of that is while in immature BCR-ABL1 transformed progenitors, Arf levels are maintained low or very low, in pre-B transformed cells are high and comparable to non-transformed controls [134-136]. Consistent with these results, the frequency of apoptotic cells in cultures initiated in transformed pre$\mathrm{B}$ cells at 72 and $96 \mathrm{~h}$ after transduction were higher compared with pro-B cells [134]. 
Therefore, in order to bypass the BCR-ABL1-Arf expression re-activation loop, the more mature B-cell progenitors need to delete the $C D K N 2 A / B$ locus to increase their oncogenic potential $[23,137]$.

The matter of which upstream signals regulate $A R F$ expression has also been explored in T-ALL, and given the similarly high level of co-occurrence with NOTCH1 activating mutations, the possible relationship between ARF and NOTCH1 has been tested using null Arf Gfp/Gfp thymocytes transduced with the ICN1+-CFP form. The study showed that a significant fraction of the $\mathrm{CFP}^{+} \mathrm{T}-\mathrm{ALL}$ cells co-expressed GFP, suggesting that the $A R F$ gene can be activated by ICN1 signaling, albeit indirectly [130]. However, other results have shown that the $A R F$ promoter can be activated before NOTCH1 mutations are acquired [138]. The same study also evaluated the relationship between $A R F$ expression activation and the LMO2 transcription factor (TF). Although the authors did not identify a direct role for $\mathrm{LMO} 2$ in inducing $A R F$ expression, they did find that the TF could cooperate with $C D K N 2 A / B$ loss to enhance self-renewal in primitive thymocytes [138]. In spite of this work, the activating stimuli that induce ARF expression under normal and leukemic conditions have not yet been elucidated.

\subsection{Role of the INK4a/ARF Proteins in Genomic Instability}

Unlike with hereditary cancers, sporadic cancers, such as ALL, show very few or no mutations in their DNA repair genes, suggesting that sporadic and hereditary cancers do not have the same etiology. Genomic instability could be induced by oncogenes instead of by the presence of mutations in DNA-repair genes. This hypothesis is based on the fact that analysis of NGS sequencing data have shown that very few genes are mutated, deleted and/or amplified at high frequencies in sporadic human cancers, those worth mentioning include the TP53 tumor suppressor and DNA damage checkpoint gene and genes that negatively regulate cell growth, such as the $C D K N 2 A / B$ genes. More importantly, very few or an absence of mutations in DNA-repair genes have been observed [139]. On the other hand, activation of growth signaling pathways induces loss of heterozygosity and genomic instability in mammalian cells cultured in vitro, human xenografts, mouse models [140-144]. These findings have led to the formulation of a mechanism by which activated oncogenes induced genomic instability involves DNA replication stress that preferentially affects common fragile sites $[140,141,145]$. In the context of leukemia, cells presenting $C D K N 2 A / B$ deletions dysregulate cell-cycle, apoptosis and senescence-signaling pathways through TP53 and RB1. These tumor cells, with increased fast cycling, would accumulate additional mutations, thereby promoting clonal heterogeneity, drug resistance and tumor progression [76,137].

On the other hand, association of $C D K N 2 A$ with telomere maintenance has been also observed. Maintenance of the in vitro growing of normal epithelial cells in a dish leads to a growth plateau in which most cells show proliferative arrest, while a small number of cells maintain good growth. These post-selected growing cells do not express CDKN2A mRNA and protein [146]. Continued proliferation of these cells leads to further telomere erosion, loss of the capping function, and entry into a phase of rampant chromosomal instability $[147,148]$. The massive genetic instability associated with this stage may well be the mechanism by which unusual cells acquire the constellation of genomic alterations needed for malignant transformation [147,149-151]. In a similar way, a correlation between $C D K N 2 A$ expression and telomere length has also been described in patients with breast cancer, in whom repression of CDKN2A/RB1 and/or TP53/CDKN1A by hypermethylation was associated with greater telomere shortening. Critical telomere shortening would lead to genome instability that ultimately produces malignant transformation [152]. Finally, more recent results have shown a TP53-independent role for INK4a/ARF at the mitotic checkpoint. Using MEFs without Arf expression, Britigan et al. have demonstrated that loss of Arf results in aneuploidy in vitro and in vivo. Arf ${ }^{-/}$MEFs exhibited mitotic defects including misaligned and lagging chromosomes, multipolar spindles, and increased tetraploidy. In addition, in these defective MEFs, overexpression of Mad2, BubR1, and Aurora B was 
observed. However, only overexpression of Aurora B phenocopied mitotic defects observed in $A f^{-/-}$MEFs [153]. Despite these data, it is important to emphasize that the functional involvement of the $C D K N 2 A / B$ gene cluster in telomere maintenance and mitotic check point regulation needs to be further explored in ALL.

\subsection{Consequences of Germline Mutations}

Very little is known about the functional consequences of germline mutations in the $C D K N 2 A / B$ locus. However, it has been shown that these variants can modify proteininteracting domains in INK4a, affecting the interaction with other proteins like MYB [154], or leading to mislocalization of the INK4a protein into the cell nucleus [153].

\section{Implications of the $C D K N 2 A / B$ Gene Cluster for Treatment Resistance/Relapse}

Comparison of the genetics in samples at diagnosis vs. relapse has helped to identify recurrent deregulated genes/pathways that are potentially responsible for relapse in ALL patients. In such an analysis, $C D K N 2 A / B$ deletions are observed at diagnosis and at relapse, with a tendency to be more frequent homozygous deletions in ALL relapse cases [78-80,155-158]. However, some studies showed no significantly higher frequency of $C D K N 2 A / B$ deletions (no homozygous or heterozygous deletions) at relapse than at diagnosis $[24,38,159,160]$. A higher level of $C D K N 2 A / B$ promoter methylation during ALL progression has also been reported [96].

Another way of evaluating the oncogenic value of a specific genetic alteration is to look into the kinetics of the relapse of patients harboring that alteration. It is well known that patients experiencing early relapses respond less well to salvage therapy than those suffering late relapses. In BCP-ALL, $C D K N 2 A / B$ deletions are significantly more closely related to early than to late relapses $[161,162]$. Some functional evidence corroborates these findings. It has been suggested that $C D K N 2 A / B$ deletions could help attenuate treatment or facilitate resistance to tyrosine kinase inhibitors (TKIs) in mouse models. Arf inactivation could contribute to drug resistance by enhancing the maintenance of leukemia-initiating cells within the hematopoietic microenvironment (bone marrow), bestowing greater fitness on leukemic cells and facilitating the more rapid emergence of resistant leukemic clones expressing mutant BCR-ABL isoforms [163].

\section{Therapeutic Approaches to Targeting the INK4 Tumor-Suppressor Protein Family}

Due to the high prevalence of $C D K N 2 A / B$ deletions in ALL patients and the fact that they are involved in regulating the cell cycle, we might have envisaged a potential use of INK4 family members as targets for exploring specific related therapies to treat ALL. However, this idea has been ruled out since these genes act as tumor suppressors in the cell. In spite of this, the regulatory function of INK4 proteins can be modulated via direct pharmacological inhibition of CDK4/CDK6 [164]. Consequently, selective and reversible inhibitors of CDK4/ 6 activity, such as palbociclib (PD0332991, Pfizer), ribociblib (LEE011, Novartis), and abemaciclib (LY2835219, Lilly), that block the cell cycle in the G1 phase and prevent leukemia progression are available and can be used to treat cancers with $C D K N 2 A / B$ losses $[165,166]$. However, when the RB1 gene is mutated, cyclin E1 and CDK2 become constitutively activated and leukemic cells become independent of the CDK4/6 pathway, which would render CDK4/6 inhibition ineffective [167]. Thus, selection of patients based on their RB mutational status is highly recommended in any clinical trial to gain efficacy from the use of CDK4/ 6 inhibitors.

Palbociclib (PD0332991, Pfizer) is an orally administered, small molecule inhibitor of CDK4/ 6 [168]. The molecule targets $R b^{w t}$ tumor cells in vitro and in vivo, inducing G1 arrest by $\mathrm{Rb}$ phosphorylation and inhibition of E2f-dependent transcription [169]. Five clinical trials of palbociclib in ALL are currently underway (https:/ / clinicaltrials.gov/). NCT03472573 is a phase I study testing the combination of palbociclib and dexamethasone in adults with recurrent and relapse BCP-ALL. Two trials (NCT03515200, NCT03792256) are testing the use of palbociclib in combination with various chemotherapeutic sched- 
ules in childhood ALL. Another clinical trial (NCT02310243) is assessing the dose and tolerability of the drug as a single agent in MLL (KMT2A) rearranged acute leukemias. The NCT03132454 trial is assessing the use of palbociclib alone or in combination with sorafenib, decitabine, or dexamethasone in recurrent and refractory acute leukemias.

LEE011 (Novartis) is an orally bioavailable small molecule that inhibits CDK4/6 at nanomolar concentrations [170]. Only one clinical trial is currently running, which is assessing the usefulness of the drug in combination with everolimus and dexamethasone in patients aged up to 30 years with refractory/relapse ALL (NCT03740334).

Abemaciclib, formerly known as LY2835219 (Eli Lilly), is the most potent orally available drug with the lowest enzymatic IC50, and like palbociclib and LEE011, is a small molecule that selectively targets CDK4/CDK6. Abemaciclib's structure enables it to cross the blood-brain barrier at low doses and it may remain on-target for longer than palbociclib, as evidenced by orthotopic (intracranial) xenografts of glioblastoma cells [168]. No clinical studies are currently being conducted with this drug in ALL patients.

It is important to emphasize that the aforementioned clinical trials involving ALL focus on targeting BCP-ALL. This makes sense since, as we have explained in this review, deletions in the $C D K N 2 A / B$ cluster give rise to distinct prognoses for the two ALL subtypes. Therefore, the selection of ALL patients tested in these clinical assays needs careful consideration.

\section{Conclusions}

Alterations in the $C D K N 2 A / B$ gene locus arise as one of the hallmarks of ALL. The frequency of the deletion in this disease varies according to the specific ALL subtype, whereby it is more prevalent in T-ALL than in BCP-ALL, and to the age group, whereby it is more prevalent in pediatric T-ALL and adult BCP-ALL cases. Moreover, $C D K N 2 A / B$ losses are associated with specific genetic lesions such as IKAROS deletions in BCP-ALL, or with the cortical subgroup in T-ALL. Surprisingly, these differences in frequency translate into a very different impact in the clinical environment. Specific association of this deletion with a particular subgroup with a marked prognosis impact (e.g., non-ETP-ALL and the Ph-like group) could be behind the contrasting clinical impacts of $C D K N 2 A / B$ deletions in the $B C P$ and T-ALL subtypes in general. In addition, the exact time during leukemogenesis when the alteration occurs may also influence the different clinical impacts of these deletions, in conjunction with some germline predisposition variants. However, the reasons why certain genetic associations present in certain patients in a particular time point of the leukemogenic process lead to different clinical outcomes are not well understood. To fill the gaps in our knowledge, we must delve deeper into the abnormal function that these genes jointly exert along the leukemogenic process. Therefore, the inclusion of more functional data to evaluate this will certainly deepen our understanding of the molecular bases of the yin and yang-like behavior of the $C D K N 2 A / B$ deletions in ALL.

Author Contributions: Conceptualization, E.G.; writing-original draft, C.G.-G., J.R. and E.G.; writing - review and editing, J.M.R. and E.G. All authors have read and agreed to the published version of the manuscript.

Funding: This project was supported by the Asociación Española Contra el Cáncer (AECC) (Project reference: GC16173697BIGA), Instituto de Salud Carlos III (Project reference: PI14/01971), CERCA Program/Generalitat de Catalunya (Project reference: 2017 SGR288 (GRC)).

Conflicts of Interest: The authors declare no conflict of interest. The funders had no role in writing or publishing the manuscript. 


\section{References}

1. Pui, C.H.; Campana, D.; Pei, D.; Bowman, W.P.; Sandlund, J.T.; Kaste, S.C.; Ribeiro, R.C.; Rubnitz, J.E.; Raimondi, S.C.; Onciu, M.; et al. Treating Childhood Acute Lymphoblastic Leukemia without Cranial Irradiation. N. Engl. J. Med. 2009, 360, $2730-2741$. [CrossRef] [PubMed]

2. Rowe, J.M.; Buck, G.; Burnett, A.K.; Chopra, R.; Wiernik, P.H.; Richards, S.M.; Lazarus, H.M.; Franklin, I.M.; Litzow, M.R.; Ciobanu, N.; et al. Induction therapy for adults with acute lymphoblastic leukemia: Results of more than 1500 patients from the international ALL trial: MRC UKALL XII/ECOG E2993. Blood 2005, 106, 3760-3767. [CrossRef] [PubMed]

3. Serrano, M.; Hannon, G.J.; Beach, D. A new regulatory motif in cell-cycle control causing specific inhibition of cyclin D/CDK4. Nature 1993, 366, 704-707. [CrossRef] [PubMed]

4. Ouelle, D.E.; Zindy, F.; Ashmun, R.A.; Sherr, C.J. Alternative reading frames of the INK4a tumor suppressor gene encode two unrelated proteins capable of inducing cell cycle arrest. Cell 1995, 83, 993-1000. [CrossRef]

5. Sharpless, N.E.; Depinho, R.A. The INK4A/ARF locus and its two gene products. Curr. Opin. Genet. Dev. 1999, 9, 22-30. [CrossRef]

6. Sherr, C.J. The INK4a/ARF network in tumour suppression. Nat. Rev. Mol. Cell Biol. 2001, 2, 731-737. [CrossRef]

7. Hannon, G.J.; Beach, D. pl5INK4B is a potentia I effector of TGF- $\beta$-induced cell cycle arrest. Nature 1994, 371, 257-261. [CrossRef]

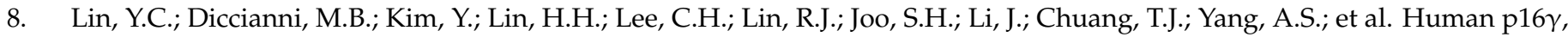
a novel transcriptional variant of p16INK4A, coexpresses with p16INK4A in cancer cells and inhibits cell-cycle progression. Oncogene 2007, 26, 7017-7027. [CrossRef]

9. Robertson, K.D.; Jones, P.A. Tissue-specific alternative splicing in the human INK4a/ARF cell cycle regulatory locus. Oncogene 1999, 18, 3810-3820. [CrossRef]

10. Tsubari, M.; Tiihonen, E.; Laiho, M. Cloning and characterization of p10, an alternatively spliced form of p15 cyclin-dependent kinase inhibitor. Cancer Res. 1997, 57, 2966-2973.

11. Georgopoulos, K. The making of a lymphocyte: The choice among disparate cell fates and the IKAROS enigma. Genes Dev. 2017, 31, 439-450. [CrossRef] [PubMed]

12. Raschke, S.; Balz, V.; Efferth, T.; Schulz, W.A.; Florl, A.R. Homozygous deletions of CDKN2A caused by alternative mechanisms in various human cancer cell lines. Genes Chromosom. Cancer 2005, 42, 58-67. [CrossRef] [PubMed]

13. Kitagawa, Y.; Inoue, K.; Sasaki, S.; Hayashi, Y.; Matsuo, Y.; Lieber, M.R.; Mizoguchi, H.; Yokota, J.; Kohno, T. Prevalent involvement of illegitimate V(D)J recombination in chromosome 9p21 deletions in lymphoid leukemia. J. Biol. Chem. 2002, $277,46289-46297$. [CrossRef] [PubMed]

14. Novara, F.; Beri, S.; Bernardo, M.E.; Bellazzi, R.; Malovini, A.; Ciccone, R.; Cometa, A.M.; Locatelli, F.; Giorda, R.; Zuffardi, O. Different molecular mechanisms causing 9p21 deletions in acute lymphoblastic leukemia of childhood. Hum. Genet. 2009, 126, 511. [CrossRef] [PubMed]

15. Papaemmanuil, E.; Rapado, I.; Li, Y.; Potter, N.E.; Wedge, D.C.; Tubio, J.; Alexandrov, L.B.; Van Loo, P.; Cooke, S.L.; Marshall, J.; et al. RAG-mediated recombination is the predominant driver of oncogenic rearrangement in ETV6-RUNX1 acute lymphoblastic leukemia. Nat. Genet. 2014, 46, 116-125. [CrossRef]

16. Cayuela, J.M.; Gardie, B.; Sigaux, F. Disruption of the multiple tumor suppressor gene MTS1/p16(INK4a)/CDKN2 by illegitimate V(D)J recombinase activity in T-cell acute lymphoblastic leukemias. Blood 1997, 90, 3720-3726. [CrossRef] [PubMed]

17. Morison, I.M.; Ellis, L.M.; Teague, L.R.; Reeve, A.E. Preferential loss of maternal 9p alleles in childhood acute lymphoblastic leukemia. Blood 2002, 99, 375-377. [CrossRef]

18. Iacobucci, I.; Ferrari, A.; Lonetti, A.; Papayannidis, C.; Paoloni, F.; Trino, S.; Storlazzi, C.T.; Ottaviani, E.; Cattina, F.; Impera, L.; et al. CDKN2A/B alterations impair prognosis in adult BCR-ABL1-positive acute lymphoblastic leukemia patients. Clin. Cancer Res. 2011, 17, 7413-7423. [CrossRef]

19. Braun, M.; Pastorczak, A.; Fendler, W.; Madzio, J.; Tomasik, B.; Taha, J.; Bielska, M.; Sedek, L.; Szczepanski, T.; Matysiak, M.; et al. Biallelic loss of CDKN2A is associated with poor response to treatment in pediatric acute lymphoblastic leukemia. Leuk. Lymphoma 2017, 58, 1162-1171. [CrossRef]

20. Schwab, C.J.; Chilton, L.; Morrison, H.; Jones, L.; Al-Shehhi, H.; Erhorn, A.; Russell, L.J.; Moorman, A.V.; Harrison, C.J. Genes commonly deleted in childhood B-cell precursor acute lymphoblastic leukemia: Association with cytogenetics and clinical features. Haematologica 2013, 98, 1081-1088. [CrossRef]

21. Paulsson, K.; Cazier, J.B.; MacDougall, F.; Stevens, J.; Stasevich, I.; Vrcelj, N.; Chaplin, T.; Lillington, D.M.; Lister, T.A.; Young, B.D. Microdeletions are a general feature of adult and adolescent acute lymphoblastic leukemia: Unexpected similarities with pediatric disease. Proc. Natl. Acad. Sci. USA 2008, 105, 6708-6713. [CrossRef] [PubMed]

22. Okamoto, R.; Ogawa, S.; Nowak, D.; Kawamata, N.; Akagi, T.; Kato, M.; Sanada, M.; Weiss, T.; Haferlach, C.; Dugas, M.; et al. Genomic profiling of adult acute lymphoblastic leukemia by single nucleotide polymorphism oligonucleotide microarray and comparison to pediatric acute lymphoblastic leukemia. Haematologica 2010, 95, 1481. [CrossRef] [PubMed]

23. Mullighan, C.G.; Miller, C.B.; Radtke, I.; Phillips, L.A.; Dalton, J.; Ma, J.; White, D.; Hughes, T.P.; Le Beau, M.M.; Pui, C.H.; et al BCR-ABL1 lymphoblastic leukaemia is characterized by the deletion of Ikaros. Nature 2008, 453, 110-114. [CrossRef] [PubMed] 
24. Sulong, S.; Moorman, A.V.; Irving, J.A.; Strefford, J.C.; Konn, Z.J.; Case, M.C.; Minto, L.; Barber, K.E.; Parker, H.; Wright, S.L.; et al. A comprehensive analysis of the CDKN2A gene in childhood acute lymphoblastic leukemia reveals genomic deletion, copy number neutral loss of heterozygosity, and association with specific cytogenetic subgroups. Blood 2009, 113, 100-107. [CrossRef] [PubMed]

25. Roberts, K.G.; Li, Y.; Payne-Turner, D.; Harvey, R.C.; Yang, Y.L.; Pei, D.; McCastlain, K.; Ding, L.; Lu, C.; Song, G.; et al. Targetable Kinase-Activating Lesions in Ph-like Acute Lymphoblastic Leukemia. N. Engl. J. Med. 2014, 371, 1005-1015. [CrossRef]

26. Pfeifer, H.; Raum, K.; Markovic, S.; Nowak, V.; Fey, S.; Obländer, J.; Pressler, J.; Böhm, V.; Brüggemann, M.; Wunderle, L.; et al. Genomic CDKN2A/2B deletions in adult Ph+ ALL are adverse despite allogeneic stem cell transplantation. Blood 2018, 131, 1464-1475. [CrossRef]

27. Steeghs, E.M.; Boer, J.M.; Hoogkamer, A.Q.; Boeree, A.; De Haas, V.; De Groot-Kruseman, H.A.; Horstmann, M.A.; Escherich, G.; Pieters, R.; Den Boer, M.L. Copy number alterations in B-cell development genes, drug resistance, and clinical outcome in pediatric B-cell precursor acute lymphoblastic leukemia. Sci. Rep. 2019, 9, 1-11. [CrossRef]

28. Ensor, H.M.; Schwab, C.; Russell, L.J.; Richards, S.M.; Morrison, H.; Masic, D.; Jones, L.; Kinsey, S.E.; Vora, A.J.; Mitchell, C.D.; et al. Demographic, clinical, and outcome features of children with acute lymphoblastic leukemia and CRLF2 deregulation: Results from the MRC ALL97 clinical trial. Blood 2011, 117, 2129-2136. [CrossRef]

29. Zaliova, M.; Potuckova, E.; Hovorkova, L.; Musilova, A.; Winkowska, L.; Fiser, K.; Stuchly, J.; Mejstrikova, E.; Starkova, J.; Zuna, J.; et al. ERG deletions in childhood acute lymphoblastic leukemia with DUX4 rearrangements are mostly polyclonal, prognostically relevant and their detection rate strongly depends on screening method sensitivity. Haematologica 2019, 104, 1407-1416. [CrossRef]

30. Russell, L.J.; Akasaka, T.; Majid, A.; Sugimoto, K.J.; Loraine Karran, E.; Nagel, I.; Harder, L.; Claviez, A.; Gesk, S.; Moorman, A.V.; et al. t(6;14)(p22;q32): A new recurrent IGH@ translocation involving ID4 in B-cell precursor acute lymphoblastic leukemia (BCP-ALL). Blood 2008, 111, 387-391. [CrossRef]

31. Passet, M.; Boissel, N.; Sigaux, F.; Saillard, C.; Bargetzi, M.; Ba, I.; Thomas, X.; Graux, C.; Chalandon, Y.; Leguay, T.; et al. PAX5 P80R mutation identifies a novel subtype of B-cell precursor acute lymphoblastic leukemia with favorable outcome. Blood 2019, 133, 280-284. [CrossRef] [PubMed]

32. Gu, Z.; Churchman, M.L.; Roberts, K.G.; Moore, I.; Zhou, X.; Nakitandwe, J.; Hagiwara, K.; Pelletier, S.; Gingras, S.; Berns, H.; et al. PAX5-driven subtypes of B-progenitor acute lymphoblastic leukemia. Nat. Genet. 2019, 51, 296-307. [CrossRef] [PubMed]

33. Mullighan, C.G.; Zhang, J.; Harvey, R.C.; Collins-Underwood, J.R.; Schulman, B.A.; Phillips, L.A.; Tasian, S.K.; Loh, M.L.; Su, X.; Liu, W.; et al. JAK mutations in high-risk childhood acute lymphoblastic leukemia. Proc. Natl. Acad. Sci. USA 2009, 106, 9414-9418. [CrossRef] [PubMed]

34. Scheijen, B.; Boer, J.M.; Marke, R.; Tijchon, E.; Van Ingen Schenau, D.; Waanders, E.; Van Emst, L.; Van Der Meer, L.T.; Pieters, R.; Escherich, G.; et al. Tumor suppressors BTG1 and IKZF1 cooperate during mouse leukemia development and increase relapse risk in B-cell precursor acute lymphoblastic leukemia patients. Haematologica 2017, 102, 541-551. [CrossRef]

35. Kathiravan, M.; Singh, M.; Bhatia, P.; Trehan, A.; Varma, N.; Sachdeva, M.S.; Bansal, D.; Jain, R.; Naseem, S. Deletion of $\mathrm{CDKN2A} / \mathrm{B}$ is associated with inferior relapse free survival in pediatric B cell acute lymphoblastic leukemia. Leuk. Lymphoma 2019, 60, 433-441. [CrossRef]

36. Heerema, N.A.; Nachman, J.B.; Sather, H.N.; Sensel, M.G.; Lee, M.K.; Hutchinson, R.; Lange, B.J.; Steinherz, P.G.; Bostrom, B.; Gaynon, P.S.; et al. Hypodiploidy with less than 45 chromosomes confers adverse risk in childhood acute lymphoblastic leukemia: A report from the children's cancer group. Blood 1999, 12, 4036-4045.

37. Moreno, T.C.; Gustafsson, G.; Garwicz, S.; Grander, D.; Jonmundsson, G.K.; Frost, B.M.; Mäkipernaa, A.; Rasool, O.; Savolainen, E.R.; Schmiegelow, K.; et al. Deletion of the Ink4-locus (the p16ink4a, p14ARF and p15ink4b genes) predicts relapse in children with ALL treated according to the Nordic protocols NOPHO-86 and NOPHO-92. Leukemia 2002, 16, 2037-2045. [CrossRef]

38. van Zutven, L.J.; van Drunen, E.; de Bont, J.M.; Wattel, M.M.; Den Boer, M.L.; Pieters, R.; Hagemeijer, A.; Slater, R.M.; Beverloo, H.B. CDKN2 deletions have no prognostic value in childhood precursor-B acute lymphoblastic leukaemia. Leukemia 2005, 19, 1281-1284. [CrossRef]

39. Mirebeau, D.; Acquaviva, C.; Suciu, S.; Bertin, R.; Dastugue, N.; Robert, A.; Boutard, P.; Méchinaud, F.; Plouvier, E.; Otten, J.; et al. The prognostic significance of CDKN2A, CDKN2B and MTAP inactivation in B-lineage acute lymphoblastic leukemia of childhood. Results of the EORTC studies 58881 and 58951. Haematologica 2006, 7, 881-885.

40. Mullighan, C.G.; Su, X.; Zhang, J.; Radtke, I.; Phillips, L.A.; Miller, C.B.; Ma, J.; Liu, W.; Cheng, C.; Schulman, B.A.; et al. Deletion of IKZF1 and Prognosis in Acute Lymphoblastic Leukemia. N. Engl. J. Med. 2009, 360, 470-480. [CrossRef]

41. Kuchinskaya, E.; Heyman, M.; Nordgren, A.; Söderhäll, S.; Forestier, E.; Wehner, P.; Vettenranta, K.; Jonsson, O.; Wesenberg, F.; Sahlén, S.; et al. Interphase fluorescent in situ hybridization deletion analysis of the 9p21 region and prognosis in childhood acute lymphoblastic leukaemia (ALL): Results from a prospective analysis of 519 Nordic patients treated according to the NOPHO-ALL 2000 protocol. Br. J. Haematol. 2011, 152, 615-622. [CrossRef] [PubMed]

42. Krentz, S.; Hof, J.; Mendioroz, A.; Vaggopoulou, R.; Dörge, P.; Lottaz, C.; Engelmann, J.C.; Groeneveld, T.W.L.; Körner, G.; Seeger, K.; et al. Prognostic value of genetic alterations in children with first bone marrow relapse of childhood B-cell precursor acute lymphoblastic leukemia. Leukemia 2013, 27, 295-304. [CrossRef] [PubMed] 
43. Forero-Castro, M.; Robledo, C.; Benito, R.; Abáigar, M.; África Martín, A.; Arefi, M.; Fuster, J.L.; de Las Heras, N.; Rodríguez, J.N.; Quintero, J.; et al. Genome-Wide DNA Copy Number Analysis of Acute Lymphoblastic Leukemia Identifies New Genetic Markers Associated with Clinical Outcome. PLoS ONE 2016, 11, e0148972. [CrossRef] [PubMed]

44. Messina, M.; Chiaretti, S.; Fedullo, A.L.; Piciocchi, A.; Puzzolo, M.C.; Lauretti, A.; Gianfelici, V.; Apicella, V.; Fazi, P.; Te Kronnie, G.; et al. Clinical significance of recurrent copy number aberrations in B-lineage acute lymphoblastic leukaemia without recurrent fusion genes across age cohorts. Br. J. Haematol. 2017, 178, 583-587. [CrossRef] [PubMed]

45. Sutton, R.; Venn, N.C.; Law, T.; Boer, J.M.; Trahair, T.N.; Ng, A.; Den Boer, M.L.; Dissanayake, A.; Giles, J.E.; Dalzell, P.; et al. A risk score including microdeletions improves relapse prediction for standard and medium risk precursor B-cell acute lymphoblastic leukaemia in children. Br. J. Haematol. 2018, 180, 550-562. [CrossRef]

46. Parker, C.; Krishnan, S.; Hamadeh, L.; Irving, J.A.; Kuiper, R.P.; Révész, T.; Hoogerbrugge, P.; Hancock, J.; Sutton, R.; Moorman, A.V.; et al. Outcomes of patients with childhood B-cell precursor acute lymphoblastic leukaemia with late bone marrow relapses: Long-term follow-up of the ALLR3 open-label randomised trial. Lancet Haematol. 2019, 6, e204-e216. [CrossRef]

47. Mullighan, C.G.; Goorha, S.; Radtke, I.; Miller, C.B.; Coustan-Smith, E.; Dalton, J.D.; Girtman, K.; Mathew, S.; Ma, J.; Pounds, S.B.; et al. Genome-wide analysis of genetic alterations in acute lymphoblastic leukaemia. Nature 2007, 446, 758-764. [CrossRef]

48. Zhang, J.; Ding, L.; Holmfeldt, L.; Wu, G.; Heatley, S.L.; Payne-Turner, D.; Easton, J.; Chen, X.; Wang, J.; Rusch, M.; et al. The genetic basis of early T-cell precursor acute lymphoblastic leukaemia. Nature 2012, 481, 157-163. [CrossRef]

49. Karrman, K.; Castor, A.; Behrendtz, M.; Forestier, E.; Olsson, L.; Ehinger, M.; Biloglav, A.; Fioretos, T.; Paulsson, K.; Johansson, B. Deep sequencing and SNP array analyses of pediatric T-cell acute lymphoblastic leukemia reveal NOTCH1 mutations in minor subclones and a high incidence of uniparental isodisomies affecting CDKN2A. J. Hematol. Oncol. 2015, 8, 1-9. [CrossRef]

50. Vicente, C.; Schwab, C.; Broux, M.; Geerdens, E.; Degryse, S.; Demeyer, S.; Lahortiga, I.; Elliott, A.; Chilton, L.; La Starza, R.; et al. Targeted sequencing identifies associations between IL7R-JAK mutations and epigenetic modulators in T-cell acute lymphoblastic leukemia. Haematologica 2015, 100, 1301-1310. [CrossRef]

51. Liu, Y.; Easton, J.; Shao, Y.; Maciaszek, J.; Wang, Z.; Wilkinson, M.R.; McCastlain, K.; Edmonson, M.; Pounds, S.B.; Shi, L.; et al. The genomic landscape of pediatric and young adult T-lineage acute lymphoblastic leukemia. Nat. Genet. 2017, 49, 1211. [CrossRef] [PubMed]

52. Yeh, T.C.; Liang, D.C.; Liu, H.C.; Jaing, T.H.; Chen, S.H.; Hou, J.Y.; Yang, C.P.; Huang, Y.J.; Yao, H.W.; Huang, T.Y.; et al. Clinical and biological relevance of genetic alterations in pediatric T-cell acute lymphoblastic leukemia in Taiwan. Pediatr. Blood Cancer 2019, 66, e27496. [CrossRef] [PubMed]

53. Noronha, E.P.; Codeço Marques, L.V.; Andrade, F.G.; Santos Thuler, L.C.; Terra-Granado, E.; Pombo-De-Oliveira, M.S. The profile of immunophenotype and genotype aberrations in subsets of pediatric T-cell acute lymphoblastic leukemia. Front. Oncol. 2019, 9, 316. [CrossRef] [PubMed]

54. Thakral, D.; Kaur, G.; Gupta, R.; Benard, A.; Savola, S.; Singh, I.K.; Anand, R.; Rani, L.; Verma, P.; Vashishtha, S.; et al. Rapid Identification of Key Copy Number Alterations in B- and T-Cell Acute Lymphoblastic Leukemia by Digital Multiplex Ligation-Dependent Probe Amplification. Front. Oncol. 2019, 9, 871. [CrossRef]

55. Moorman, A.V.; Harrison, C.J.; Buck, G.A.; Richards, S.M.; Secker-Walker, L.M.; Martineau, M.; Vance, G.H.; Cherry, A.M.; Higgins, R.R.; Fielding, A.K.; et al. Karyotype is an independent prognostic factor in adult acute lymphoblastic leukemia (ALL): Analysis of cytogenetic data from patients treated on the Medical Research Council (MRC) UKALLXII/Eastern Cooperative Oncology Group (ECOG) 2993 trial. Blood 2007, 109, 3189-3197.

56. Nahi, H.; Hägglund, H.; Ahlgren, T.; Bernell, P.; Hardling, M.; Karlsson, K.; Lazarevic, V.L.; Linderholm, M.; Smedmyr, B.; Åström, M.; et al. An investigation into whether deletions in 9p reflect prognosis in adult precursor B-cell acute lymphoblastic leukemia: a multi-center study of 381 patients. Haematologica 2008, 93, 1734-1738. [CrossRef]

57. Yanada, M.; Takeuchi, J.; Sugiura, I.; Akiyama, H.; Usui, N.; Yagasaki, F.; Nishii, K.; Ueda, Y.; Takeuchi, M.; Miyawaki, S.; et al. Karyotype at diagnosis is the major prognostic factor predicting relapse-free survival for patients with Philadelphia chromosome-positive acute lymphoblastic leukemia treated with imatinib-combined chemotherapy. Haematologica 2008, 93, 287-290. [CrossRef]

58. Moorman, A.V.; Schwab, C.; Ensor, H.M.; Russell, L.J.; Morrison, H.; Jones, L.; Masic, D.; Patel, B.; Rowe, J.M.; Tallman, M.; et al. IGH@ translocations, CRLF2 deregulation, and microdeletions in adolescents and adults with acute lymphoblastic leukemia. J. Clin. Oncol. 2012, 30, 3100-3108. [CrossRef]

59. Ribera, J.; Morgades, M.; Zamora, L.; Montesinos, P.; Gómez-Seguí, I.; Pratcorona, M.; Sarrà, J.; Guàrdia, R.; Nomdedeu, J.; Tormo, M.; et al. Prognostic significance of copy number alterations in adolescent and adult patients with precursor B acute lymphoblastic leukemia enrolled in PETHEMA protocols. Cancer 2015, 121, 3809-3817. [CrossRef]

60. Xu, N.; Li, Y.L.; Zhou, X.; Cao, R.; Li, H.; Lu, Q.S.; Li, L.; Lu, Z.Y.; Huang, J.X.; Sun, J.; et al. CDKN2 Gene Deletion as Poor Prognosis Predictor Involved in the Progression of Adult B-Lineage Acute Lymphoblastic Leukemia Patients. J. Cancer 2015, 6, 1114. [CrossRef]

61. Xu, N.; Li, Y.L.; Li, X.; Zhou, X.; Cao, R.; Li, H.; Li, L.; Lu, Z.Y.; Huang, J.X.; Fan, Z.P.; et al. Correlation between deletion of the CDKN2 gene and tyrosine kinase inhibitor resistance in adult Philadelphia chromosome-positive acute lymphoblastic leukemia. J. Hematol. Oncol. 2016, 9, 40. [CrossRef] [PubMed] 
62. Seol, C.A.; Cho, Y.U.; Jang, S.; Park, C.J.; Lee, J.H.; Lee, J.H.; Lee, K.H.; Seo, E.J. Prognostic significance of recurrent additional chromosomal abnormalities in adult patients with Philadelphia chromosome-positive acute lymphoblastic leukemia. Cancer Genet. 2017, 216, 29-36. [CrossRef] [PubMed]

63. Patel, S.; Mason, C.C.; Glenn, M.J.; Paxton, C.N.; South, S.T.; Cessna, M.H.; Asch, J.; Cobain, E.F.; Bixby, D.L.; Smith, L.B.; et al. Genomic analysis of adult B-ALL identifies potential markers of shorter survival. Leuk. Res. 2017, 56, 44-51. [CrossRef] [PubMed]

64. Short, N.J.; Kantarjian, H.M.; Sasaki, K.; Ravandi, F.; Ko, H.; Cameron Yin, C.; Garcia-Manero, G.; Cortes, J.E.; Garris, R.; O’Brien, S.M.; et al. Outcomes associated with $+\operatorname{der}(22) t(9 ; 22)$ and $-9 / 9 p$ in patients with Philadelphia chromosome-positive acute lymphoblastic leukemia receiving chemotherapy plus a tyrosine kinase inhibitor. Am. J. Hematol. 2017, 92, 238-243. [CrossRef]

65. Lafage-Pochitaloff, M.; Baranger, L.; Hunault, M.; Cuccuini, W.; Lefebvre, C.; Bidet, A.; Tigaud, I.; Eclache, V.; Delabesse, E.; Bilhou-Nabéra, C.; et al. Impact of cytogenetic abnormalities in adults with Ph-negative B-cell precursor acute lymphoblastic leukemia. Blood 2017, 130, 1832-1844. [CrossRef]

66. Fedullo, A.L.; Messina, M.; Elia, L.; Piciocchi, A.; Gianfelici, V.; Lauretti, A.; Soddu, S.; Puzzolo, M.C.; Minotti, C.; Ferrara, F.; et al. Prognostic implications of additional genomic lesions in adult Philadelphia chromosome-positive acute lymphoblastic leukemia. Haematologica 2019, 104, 312-318. [CrossRef]

67. Ribera, J.; Zamora, L.; Morgades, M.; Vives, S.; Granada, I.; Montesinos, P.; Gómez-Seguí, I.; Mercadal, S.; Guàrdia, R.; Nomdedeu, J.; et al. Molecular profiling refines minimal residual disease-based prognostic assessment in adults with Philadelphia chromosome-negative B-cell precursor acute lymphoblastic leukemia. Genes Chromosom. Cancer 2019, 58, 815-819. [CrossRef]

68. Sánchez, R.; Ribera, J.; Morgades, M.; Ayala, R.; Onecha, E.; Ruiz-Heredia, Y.; Juárez-Rufián, A.; de Nicolás, R.; Sánchez-Pina, J.; Vives, S.; et al. A novel targeted RNA-Seq panel identifies a subset of adult patients with acute lymphoblastic leukemia with BCR-ABL1-like characteristics. Blood Cancer J. 2020, 10, 1-11. [CrossRef]

69. Marks, D.I.; Paietta, E.M.; Moorman, A.V.; Richards, S.M.; Buck, G.; DeWald, G.; Ferrando, A.; Fielding, A.K.; Goldstone, A.H.; Ketterling, R.P.; et al. T-cell acute lymphoblastic leukemia in adults: Clinical features, immunophenotype, cytogenetics, and outcome from the large randomized prospective trial (UKALL XII/ECOG 2993). Blood 2009, 114, 5136-5145. [CrossRef]

70. Grossmann, V.; Haferlach, C.; Weissmann, S.; Roller, A.; Schindela, S.; Poetzinger, F.; Stadler, K.; Bellos, F.; Kern, W.; Haferlach, T.; et al. The molecular profile of adult T-cell acute lymphoblastic leukemia: Mutations in RUNX1 and DNMT3A are associated with poor prognosis in T-ALL. Genes Chromosom. Cancer 2013, 52, 410-422. [CrossRef]

71. Van Vlierberghe, P.; Ambesi-Impiombato, A.; De Keersmaecker, K.; Hadler, M.; Paietta, E.; Tallman, M.S.; Rowe, J.M.; Forne, C.; Rue, M.; Ferrando, A.A. Prognostic relevance of integrated genetic profiling in adult T-cell acute lymphoblastic leukemia. Blood 2013, 122, 74-82. [PubMed]

72. Dirse, V.; Bertasiute, A.; Gineikiene, E.; Zvirblis, T.; Dambrauskiene, R.; Gerbutavicius, R.; Juozaityte, E.; Malciute, L.; Paulsson, K.; Griskevicius, L. A population-based single nucleotide polymorphism array analysis of genomic aberrations in younger adult acute lymphoblastic leukemia patients. Genes Chromosom. Cancer 2015, 54, 326-333. [CrossRef] [PubMed]

73. Fang, Q.; Yuan, T.; Li, Y.; Feng, J.; Gong, X.; Li, Q.; Zhao, X.; Liu, K.; Tang, K.; Tian, Z.; et al. Prognostic significance of copy number alterations detected by multi-link probe amplification of multiple genes in adult acute lymphoblastic leukemia. Oncol. Lett. 2018, 15, 5359-5367. [CrossRef] [PubMed]

74. Genescà, E.; Lazarenkov, A.; Morgades, M.; Berbis, G.; Ruíz-Xivillé, N.; Gómez-Marzo, P.; Ribera, J.; Juncà, J.; González-Pérez, A.; Mercadal, S.; et al. Frequency and clinical impact of CDKN2A/ARF/CDKN2B gene deletions as assessed by in-depth genetic analyses in adult $\mathrm{T}$ cell acute lymphoblastic leukemia. J. Hematol. Oncol. 2018, 11, 1-4.

75. Jang, W.; Park, J.; Kwon, A.; Choi, H.; Kim, J.; Lee, G.D.; Han, E.; Jekarl, D.W.; Chae, H.; Han, K.; et al. CDKN2B downregulation and other genetic characteristics in T-acute lymphoblastic leukemia. Exp. Mol. Med. 2019, 51, 1-15. [CrossRef]

76. Notta, F.; Mullighan, C.G.; Wang, J.C.; Poeppl, A.; Doulatov, S.; Phillips, L.A.; Ma, J.; Minden, M.D.; Downing, J.R.; Dick, J.E. Evolution of human BCR-ABL1 lymphoblastic leukaemia-initiating cells. Nature 2011, 469, 362. [CrossRef]

77. Schmitz, M.; Breithaupt, P.; Scheidegger, N.; Cario, G.; Bonapace, L.; Meissner, B.; Mirkowska, P.; Tchinda, J.; Niggli, F.K.; Stanulla, M.; et al. Xenografts of highly resistant leukemia recapitulate the clonal composition of the leukemogenic compartment. Blood 2011, 118, 1854-1864. [CrossRef]

78. Mullighan, C.G.; Phillips, L.A.; Su, X.; Ma, J.; Miller, C.B.; Shurtleff, S.A.; Downing, J.R. Genomic analysis of the clonal origins of relapsed acute lymphoblastic leukemia. Science 2008, 322, 1377-1380.

79. van Delft, F.W.; Horsley, S.; Colman, S.; Anderson, K.; Bateman, C.; Kempski, H.; Zuna, J.; Eckert, C.; Saha, V.; Kearney, L.; et al. Clonal origins of relapse in ETV6-RUNX1 acute lymphoblastic leukemia. Blood 2011, 117, 6247-6254.

80. Ribera, J.; Zamora, L.; Morgades, M.; Mallo, M.; Solanes, N.; Batlle, M.; Vives, S.; Granada, I.; Juncà, J.; Malinverni, R.; et al. Copy number profiling of adult relapsed B-cell precursor acute lymphoblastic leukemia reveals potential leukemia progression mechanisms. Genes Chromosom. Cancer 2017, 56, 810-820.

81. Hebert, J.; Cayuela, J.M.; Berkeley, J.; Sigaux, F. Candidate tumor-suppressor genes MTS1 (p16INK4A) and MTS2 (p15INK4B) display frequent homozygous deletions in primary cells from T- but not from B-cell lineage acute lymphoblastic leukemias. Blood 1994, 84, 4038-4044. [CrossRef] [PubMed]

82. Vitale, A. Adult T-cell acute lymphoblastic leukemia: Biologic profile at presentation and correlation with response to induction treatment in patients enrolled in the GIMEMA LAL 0496 protocol. Blood 2006, 107, 473-479. [PubMed] 
83. Studniak, E.; Maloney, E.; Ociepa, T.; Urasiński, T.; Skonieczka, K.; Haus, O.; Poluha, A.; Kowalczyk, J.; Zajączek, S. Allelic loss of selected tumor suppressor genes in acute lymphoblastic leukemia in children. Polish J. Pathol. 2013, 64, 121-128. [CrossRef] [PubMed]

84. Coustan-Smith, E.; Mullighan, C.G.; Onciu, M.; Behm, F.G.; Raimondi, S.C.; Pei, D.; Cheng, C.; Su, X.; Rubnitz, J.E.; Basso, G.; et al. Early T-cell precursor leukaemia: A subtype of very high-risk acute lymphoblastic leukaemia. Lancet Oncol. 2009, 10, 147-156. [CrossRef]

85. Ferrando, A.A.; Neuberg, D.S.; Staunton, J.; Loh, M.L.; Huard, C.; Raimondi, S.C.; Behm, F.G.; Pui, C.H.; Downing, J.R.; Gilliland, D.G.; et al. Gene expression signatures define novel oncogenic pathways in T cell acute lymphoblastic leukemia. Cancer Cell 2002, 1, 75-87. [CrossRef]

86. Homminga, I.; Pieters, R.; Langerak, A.W.; de Rooi, J.J.; Stubbs, A.; Verstegen, M.; Vuerhard, M.; Buijs-Gladdines, J.; Kooi, C.; Klous, P.; et al. Integrated Transcript and Genome Analyses Reveal NKX2-1 and MEF2C as Potential Oncogenes in T Cell Acute Lymphoblastic Leukemia. Cancer Cell 2011, 19, 484-497. [CrossRef]

87. La Starza, R.; Borga, C.; Barba, G.; Pierini, V.; Schwab, C.; Matteucci, C.; Lema Fernandez, A.G.; Leszl, A.; Cazzaniga, G.; Chiaretti, S.; et al. Genetic profile of T-cell acute lymphoblastic leukemias with MYC translocations. Blood 2014, 124, 3577-3582. [CrossRef]

88. Milani, G.; Matthijssens, F.; Van Loocke, W.; Durinck, K.; Roels, J.; Peirs, S.; Thénoz, M.; Pieters, T.; Reunes, L.; Lintermans, B.; et al. Genetic characterization and therapeutic targeting of MYC -rearranged T cell acute lymphoblastic leukaemia. Br. J. Haematol. 2019, 185, 169-174.

89. Herman, J.G.; Civin, C.I.; Issa, J.P.J.; Collector, M.I.; Sharkis, S.J.; Baylin, S.B. Distinct patterns of inactivation of p15INK4B and p16INK4A characterize the major types of hematological malignancies. Cancer Res. 1997, 5, 837-841.

90. Batova, A.; Diccianni, M.B.; John, C.Y.; Nobori, T.; Link, M.P.; Pullen, J.; Alice, L.Y. Frequent and selective methylation of p15 and deletion of both p15 and p16 in T-cell acute lymphoblastic leukemia. Cancer Res. 1997, 5, 832-836.

91. Tsellou, E.; Troungos, C.; Moschovi, M.; Athanasiadou-Piperopoulou, F.; Polychronopoulou, S.; Kosmidis, H.; Kalmanti, M.; Hatzakis, A.; Dessypris, N.; Kalofoutis, A.; et al. Hypermethylation of CpG islands in the promoter region of the p15INK4B gene in childhood acute leukaemia. Eur. J. Cancer 2005, 41, 584-589. [CrossRef] [PubMed]

92. Takeuchi, S.; Matsushita, M.; Zimmermann, M.; Ikezoe, T.; Komatsu, N.; Seriu, T.; Schrappe, M.; Bartram, C.R.; Koeffler, H.P. Clinical significance of aberrant DNA methylation in childhood acute lymphoblastic leukemia. Leuk. Res. 2011, 35, 1345-1349. [CrossRef] [PubMed]

93. Mai, H.; Liu, X.; Chen, Y.; Li, C.; Cao, L.; Chen, X.; Chen, S.; Liu, G.; Wen, F. Hypermethylation of p15 gene associated with an inferior poor long-term outcome in childhood acute lymphoblastic leukemia. J. Cancer Res. Clin. Oncol. 2016, 142, 497-504. [CrossRef]

94. Chim, C.S.; Tam, C.Y.; Liang, R.; Kwong, Y.L. Methylation of p15 and p16 genes in adult acute leukemia: Lack of prognostic significance. Cancer 2001, 12, 2222-2229. [CrossRef]

95. Hoshino, K.; Asou, N.; Okubo, T.; Suzushima, H.; Kiyokawa, T.; Kawano, F.; Mitsuya, H. The absence of the p15 INK4B gene alterations in adult patients with precursor B-cell acute lymphoblastic leukaemia is a favourable prognostic factor. Br. J. Haematol. 2002, 117, 531-540. [CrossRef]

96. Garcia-Manero, G.; Daniel, J.; Smith, T.L.; Kornblau, S.M.; Lee, M.S.; Kantarjian, H.M.; Issa, J.P.J. DNA methylation of multiple promoter-associated CpG islands in adult acute lymphocytic leukemia. Clin. Cancer Res. 2002, 8, 2217-2224.

97. Bueso-Ramos, C.; Xu, Y.; McDonnell, T.J.; Brisbay, S.; Pierce, S.; Kantarjian, H.; Rosner, G.; Garcia-Manero, G. Protein Expression of a Triad of Frequently Methylated Genes, $p 73$, p57 Kip2 , and $p 15$, Has Prognostic Value in Adult Acute Lymphocytic Leukemia Independently of Its Methylation Status. J. Clin. Oncol. 2005, 23, 3932-3939.

98. Yang, H.; Kadia, T.; Xiao, L.; Bueso-Ramos, C.E.; Hoshino, K.; Thomas, D.A.; O’Brien, S.; Jabbour, E.; Pierce, S.; Rosner, G.L.; et al. Residual DNA methylation at remission is prognostic in adult Philadelphia chromosome-negative acute lymphocytic leukemia. Blood 2009, 113, 1892-1898. [CrossRef]

99. Garcia-Manero, G.; Jeha, S.; Daniel, J.; Williamson, J.; Albitar, M.; Kantarjian, H.M.; Issa, J.P.J. Aberrant DNA methylation in pediatric patients with acute lymphocytic leukemia. Cancer 2003, 97, 695-702. [CrossRef]

100. Sherborne, A.L.; Hosking, F.J.; Prasad, R.B.; Kumar, R.; Koehler, R.; Vijayakrishnan, J.; Papaemmanuil, E.; Bartram, C.R.; Stanulla, M.; Schrappe, M.; et al. Variation in CDKN2A at 9p21.3 influences childhood acute lymphoblastic leukemia risk. Nat. Genet. 2010, 42, 492-494. [CrossRef]

101. Hungate, E.A.; Vora, S.R.; Gamazon, E.R.; Moriyama, T.; Best, T.; Hulur, I.; Lee, Y.; Evans, T.J.; Ellinghaus, E.; Stanulla, M.; et al. A variant at 9p21.3 functionally implicates CDKN2B in paediatric B-cell precursor acute lymphoblastic leukaemia aetiology. Nat. Commun. 2016, 7, 1-11.

102. Xu, H.; Zhang, H.; Yang, W.; Yadav, R.; Morrison, A.C.; Qian, M.; Devidas, M.; Liu, Y.; Perez-Andreu, V.; Zhao, X.; et al. Inherited coding variants at the CDKN2A locus influence susceptibility to acute lymphoblastic leukaemia in children. Nat. Commun. 2015, $6,1-7$.

103. Walsh, K.M.; De Smith, A.J.; Hansen, H.M.; Smirnov, I.V.; Gonseth, S.; Endicott, A.A.; Xiao, J.; Rice, T.; Fu, C.H.; McCoy, L.S.; et al. A heritable missense polymorphism in CDKN2A confers strong risk of childhood acute lymphoblastic leukemia and is preferentially selected during clonal evolution. Cancer Res. 2015, 75, 4884-4894. [CrossRef] [PubMed]

104. Knudson, A.G. Two genetic hits (more or less) to cancer. Nat. Rev. Cancer 2001, 1, 157-162. [CrossRef] [PubMed] 
105. Mullighan, C.G. The molecular genetic makeup of acute lymphoblastic leukemia. In Hematology 2010, the American Society of Hematology Education Program Book; American Society of Hematology: Washington, DC, USA, 2012; Volume 2012, pp. 389-396.

106. Brown, A.L.; De Smith, A.J.; Gant, V.U.; Yang, W.; Scheurer, M.E.; Walsh, K.M.; Chernus, J.M.; Kallsen, N.A.; Peyton, S.A.; Davies, G.E.; et al. Inherited genetic susceptibility to acute lymphoblastic leukemia in down syndrome. Blood 2019, 134, $1227-1237$. [CrossRef] [PubMed]

107. Toubai, T.; Tanaka, J.; Ota, S.; Fukuhara, T.; Hashino, S.; Kondo, T.; Kasai, M.; Kakinoki, Y.; Masauzi, N.; Morioka, M.; et al. Minimal residual disease (MRD) monitoring using rearrangement of T-cell receptor and immunoglobulin $\mathrm{H}$ gene in the treatment of adult acute lymphoblastic leukemia patients. Am. J. Hematol. 2005, 80, 181-187. [CrossRef] [PubMed]

108. Borowitz, M.J.; Devidas, M.; Hunger, S.P.; Bowman, W.P.; Carroll, A.J.; Carroll, W.L.; Linda, S.; Martin, P.L.; Pullen, D.J.; Viswanatha, D.; et al. Clinical significance of minimal residual disease in childhood acute lymphoblastic leukemia and its relationship to other prognostic factors: A Children's Oncology Group study. Blood 2008, 111, 5477-5485. [CrossRef]

109. Stanulla, M.; Dagdan, E.; Zaliova, M.; Bourquin, J.P.; Bornhauser, B. IKZF1 plus Defines a New Minimal Residual DiseaseDependent Very-Poor Prognostic Profile in Pediatric B-Cell Precursor Acute Lymphoblastic Leukemia. J. Clin. Oncol. 2018, 36, 1240-1249.

110. Den Boer, M.L.; van Slegtenhorst, M.; De Menezes, R.X.; Cheok, M.H.; Buijs-Gladdines, J.G.; Peters, S.T.; Van Zutven, L.J.; Beverloo, H.B.; Van der Spek, P.J.; Escherich, G.; et al. A subtype of childhood acute lymphoblastic leukaemia with poor treatment outcome: A genome-wide classification study. Lancet Oncol. 2009, 10, 125-134. [CrossRef]

111. Karrman, K.; Forestier, E.; Heyman, M.; Andersen, M.K.; Autio, K.; Blennow, E.; Borgström, G.; Ehrencrona, H.; Golovleva, I.; Heim, S.; et al. Clinical and cytogenetic features of a population-based consecutive series of 285 pediatric T-cell acute lymphoblastic leukemias: Rare T-cell receptor gene rearrangements are associated with poor outcome. Genes Chromosom. Cancer 2009, 48, 795-805. [CrossRef]

112. Russo, A.A.; Tong, L.; Lee, J.-O.; Jeffrey, P.D.; Pavletich, N.P. Structural basis for inhibition of the cyclin-dependent kinase Cdk6 by the tumour suppressor p16INK4a. Nature 1998, 395, 237-243. [CrossRef] [PubMed]

113. Kamijo, T.; Zindy, F.; Roussel, M.F.; Quelle, D.E.; Downing, J.R.; Ashmun, R.A.; Grosveld, G.; Sherr, C.J. Tumor Suppression at the Mouse INK4a Locus Mediated by the Alternative Reading Frame Product p19 ARF. Cell 1997, 91, 649-659. [CrossRef]

114. Chin, L.; Pomerantz, J.; Polsky, D.; Jacobson, M.; Cohen, C.; Cordon-Cardo, C.; Horner, J.W.; DePinho, R.A. Cooperative effects of INK4a and ras in melanoma susceptibility in vivo. Genes Dev. 1997, 11, 2822-2834. [CrossRef] [PubMed]

115. Pomerantz, J.; Schreiber-Agus, N.; Liégeois, N.J.; Silverman, A.; Alland, L.; Chin, L.; Potes, J.; Chen, K.; Orlow, I.; Lee, H.W.; et al. The Ink4a tumor suppressor gene product, p19(Arf), interacts with MDM2 and neutralizes MDM2's inhibition of p53. Cell 1998, 92, 713-723. [CrossRef]

116. Zhang, Y.; Xiong, Y.; Yarbrough, W.G. ARF promotes MDM2 degradation and stabilizes p53: ARF-INK4a locus deletion impairs both the $\mathrm{Rb}$ and 553 tumor suppression pathways. Cell 1998, 92, 725-734. [CrossRef]

117. Kamijo, T.; Weber, J.D.; Zambetti, G.; Zindy, F.; Roussel, M.F.; Sherr, C.J. Functional and physical interactions of the ARF tumor suppressor with p53 and Mdm2. Proc. Natl. Acad. Sci. USA 1998, 95, 8292-8297. [CrossRef]

118. Stott, F.J.; Bates, S.; James, M.C.; McConnell, B.B.; Starborg, M.; Brookes, S.; Palmero, I.; Ryan, K.; Hara, E.; Vousden, K.H.; et al. The alternative product from the human CDKN2A locus, p14(ARF), participates in a regulatory feedback loop with p53 and MDM2. EMBO J. 1998, 17, 5001-5014. [CrossRef]

119. Serrano, M.; Lee, H.W.; Chin, L.; Cordon-Cardo, C.; Beach, D.; DePinho, R.A. Role of the INK4a locus in tumor suppression and cell mortality. Cell 1996, 85, 27-37. [CrossRef]

120. Krimpenfort, P.; Quon, K.C.; Mooi, W.J.; Loonstra, A.; Berns, A. Loss of p16Ink4a confers susceptibility to metastatic melanoma in mice. Nature 2001, 413, 83-86. [CrossRef]

121. Sharpless, N.E.; Bardeesy, N.; Lee, K.H.; Carrasco, D.; Castrillon, D.H.; Aguirre, A.J.; Wu, E.A.; Horner, J.W.; DePinho, R.A. Loss of p16Ink4a with retention of p19Arf predisposes mice to tumorigenesis. Nature 2001, 413, 86-91.

122. Williams, R.T.; Sherr, C.J. The INK4-ARF (CDKN2A/B) locus in hematopoiesis and BCR-ABL-induced leukemias. Cold Spring Harb. Symp. Quant. Biol. 2008, 73, 461-467. [CrossRef] [PubMed]

123. Jacobs, J.L.; Kieboom, K.; Marino, S.; DePinho, R.A.; Van Lohuizen, M. The oncogene and Polycombgroup gene bmi-1 regulates cell proliferation and senescence through the ink4a locus. Nature 1999, 397, 164-168. [CrossRef] [PubMed]

124. Lessard, J.; Sauvageau, G. Bmi-1 determines the proliferative capacity of normal and leukaemic stem cells. Nature 2003, 423, 164-168. [CrossRef] [PubMed]

125. Park, I.K.; Qian, D.; Kiel, M.; Becker, M.W.; Pihalja, M.; Weissman, I.L.; Morrison, S.J.; Clarke, M.F. Bmi-1 is required for maintenance of adult self-renewing haematopoietic stem cells. Nature 2003, 423, 302-305. [CrossRef]

126. Iwama, A.; Oguro, H.; Negishi, M.; Kato, Y.; Morita, Y.; Tsukui, H.; Ema, H.; Kamijo, T.; Katoh-Fukui, Y.; Koseki, H.; et al. Enhanced self-renewal of hematopoietic stem cells mediated by the polycomb gene product Bmi-1. Immunity 2004, $21,843-851$. [CrossRef]

127. Akala, O.O.; Park, I.K.; Qian, D.; Pihalja, M.; Becker, M.W.; Clarke, M.F. Long-term haematopoietic reconstitution by Trp53-/-p16 Ink4a-/-p19Arf-/- multipotent progenitors. Nature 2008, 453, 228-232. [CrossRef]

128. Volanakis, E.J.; Boothby, M.R.; Sherr, C.J. Epigenetic regulation of the Ink4a-Arf (Cdkn2a) tumor suppressor locus in the initiation and progression of Notch1-driven T cell acute lymphoblastic leukemia. Exp. Hematol. 2013, 41, 377-386. [CrossRef] 
129. Cao, R.; Wang, L.; Wang, H.; Xia, L.; Erdjument-Bromage, H.; Tempst, P.; Jones, R.S.; Zhang, Y. Role of histone H3 lysine 27 methylation in polycomb-group silencing. Science 2002, 298, 1039-1043. [CrossRef]

130. Volanakis, E.J.; Williams, R.T.; Sherr, C.J. Stage-specific Arf tumor suppression in Notch1-induced T-cell acute lymphoblastic leukemia. Blood 2009, 114, 4451-4459. [CrossRef]

131. Chan, L.C.; Karhi, K.K.; Rayter, S.I.; Heisterkamp, N.; Eridani, S.; Powle, R.; Lawler, S.D.; Groffen, J.; Foulkes, J.G.; Greaves, M.F.; et al. A novel abl protein expressed in Philadelphia chromosome positive acute lymphoblastic leukaemia positive acute lymphoblastic leukaemia. Nature 1987, 325, 635-637. [CrossRef]

132. Clark, S.S.; Mclaughlin, J.; Crist, W.M.; Champlin, R.; Witte, O.N. Unique forms of the abl tyrosine kinase distinguish Ph1-positive CML from Ph1-positive ALL. Science 1987, 235, 85-88. [CrossRef] [PubMed]

133. Castor, A.; Nilsson, L.; Åstrand-Grundström, I.; Buitenhuis, M.; Ramirez, C.; Anderson, K.; Strömbeck, B.; Garwicz, S.; Békássy, A.N.; Schmiegelow, K.; et al. Distinct patterns of hematopoietic stem cell involvement in acute lymphoblastic leukemia. Nat. Med. 2005, 11, 630-637. [CrossRef] [PubMed]

134. Signer, R.A.J.; Montecino-Rodriguez, E.; Witte, O.N.; Dorshkind, K. Immature B-cell progenitors survive oncogenic stress and efficiently initiate Ph+ B-acute lymphoblastic leukemia. Blood 2010, 116, 2522-2530. [CrossRef] [PubMed]

135. Williams, R.T.; Roussel, M.F.; Sherr, C.J. Arf gene loss enhances oncogenicity and limits imatinib response in mouse models of Bcr-Abl-induced acute lymphoblastic leukemia. Proc. Natl. Acad. Sci. USA 2006, 103, 6688-6693. [CrossRef] [PubMed]

136. Wang, P.Y.; Young, F.; Chen, C.Y.; Stevens, B.M.; Neering, S.J.; Rossi, R.M.; Bushnell, T.; Kuzin, I.; Heinrich, D.; Bottaro, A.; et al. The biologic properties of leukemias arising from BCR/ABL-mediated transformation vary as a function of developmental origin and activity of the p19ARF gene. Blood 2008, 112, 4184-4192. [CrossRef] [PubMed]

137. Mullighan, C.G.; Williams, R.T.; Downing, J.R.; Sherr, C.J. Failure of CDKN2A/B (INK4A/B-ARF)-mediated tumor suppression and resistance to targeted therapy in acute lymphoblastic leukemia induced by BCR-ABL. Genes Dev. 2008, 22, 1411-1415. [CrossRef]

138. Treanor, L.M.; Volanakis, E.J.; Zhou, S.; Lu, T.; Sherr, C.J.; Sorrentino, B.P. Functional interactions between Lmo2, the Arf tumor suppressor, and Notch1 in murine T-cell malignancies. Blood 2011, 117, 5453-5462. [CrossRef]

139. Negrini, S.; Gorgoulis, V.G.; Halazonetis, T.D. Genomic instability an evolving hallmark of cancer. Nat. Rev. Mol. Cell Biol. 2010, 11, 220-228. [CrossRef]

140. Gorgoulis, V.G.; Vassiliou, L.V.F.; Karakaidos, P.; Zacharatos, P.; Kotsinas, A.; Liloglou, T.; Venere, M.; DiTullio, R.A.; Kastrinakis, N.G.; Levy, B.; et al. Activation of the DNA damage checkpoint and genomic instability in human precancerous lesions. Nature 2005, 434, 907-913. [CrossRef]

141. Bartkova, J.; Hořejší, Z.; Koed, K.; Krämer, A.; Tort, F.; Zieger, K.; Guldberg, P.; Sehested, M.; Nesland, J.M.; Lukas, C.; et al. DNA damage response as a candidate anti-cancer barrier in early human tumorigenesis. Nature 2005, 434, 864-870. [CrossRef]

142. Denko, N.C.; Giaccia, A.J.; Stringer, J.R.; Stambrook, P.J. The human Ha-ras oncogene induces genomic instability in murine fibroblasts within one cell cycle. Proc. Natl. Acad. Sci. USA 1994, 91, 5124-5128. [CrossRef] [PubMed]

143. Spruck, C.H.; Won, K.-A.; Reed, S.I. Deregulated cyclin E induces chromosome instability. Nature 1999, 401, 297-300. [CrossRef] [PubMed]

144. Tanaka, S. Deregulated G1-cyclin expression induces genomic instability by preventing efficient pre-RC formation. Genes Dev. 2002, 16, 2639-2649. [CrossRef] [PubMed]

145. Tsantoulis, P.K.; Kotsinas, A.; Sfikakis, P.P.; Evangelou, K.; Sideridou, M.; Levy, B.; Mo, L.; Kittas, C.; Wu, X.R.; Papavassiliou, A.G.; et al. Oncogene-induced replication stress preferentially targets common fragile sites in preneoplastic lesions. A genomewide study. Oncogene 2008, 27, 3256-3264. [CrossRef] [PubMed]

146. Brenner, A.J.; Stampfer, M.R.; Aldaz, C.M. Increased p16 expression with first senescence arrest in human mammary epithelial cells and extended growth capacity with p16 inactivation. Oncogene 1998, 17, 199-205. [CrossRef] [PubMed]

147. Counter, C.M.; Avilion, A.A.; LeFeuvre, C.E.; Stewart, N.G.; Greider, C.W.; Harley, C.B.; Bacchetti, S. Telomere shortening associated with chromosome instability is arrested in immortal cells which express telomerase activity. EMBO J. 1992, 5, 1921-1929. [CrossRef]

148. Rogan, E.M.; Bryan, T.M.; Hukku, B.; Maclean, K.; Chang, A.C.; Moy, E.L.; Englezou, A.; Warneford, S.G.; Dalla-Pozza, L.; Reddel, R.R. Alterations in p53 and p16INK4 expression and telomere length during spontaneous immortalization of Li-Fraumeni syndrome fibroblasts. Mol. Cell. Biol. 1995, 15, 4745-4753. [CrossRef]

149. De Lange, T.; Shiue, L.; Myers, R.M.; Cox, D.R.; Naylor, S.L.; Killery, A.M.; Varmus, H.E. Structure and variability of human chromosome ends. Mol. Cell. Biol. 1990, 10, 518-527. [CrossRef]

150. Hastie, N.D.; Dempster, M.; Dunlop, M.G.; Thompson, A.M.; Green, D.K.; Allshire, R.C. Telomere reduction in human colorectal carcinoma and with ageing. Nature 1990, 346, 866-868. [CrossRef]

151. Harley, C.B.; Vaziri, H.; Counter, C.M.; Allsopp, R.C. The telomere hypothesis of cellular aging. Exp. Gerontol. 1992, 27, 375-382. [CrossRef]

152. Radpour, R.; Barekati, Z.; Haghighi, M.M.; Kohler, C.; Asadollahi, R.; Torbati, P.M.; Holzgreve, W.; Zhong, X.Y. Correlation of telomere length shortening with promoter methylation profile of $\mathrm{p} 16 / \mathrm{Rb}$ and $\mathrm{p} 53 / \mathrm{p} 21$ pathways in breast cancer. Mod. Pathol. 2010, 23, 763-772. [CrossRef] [PubMed]

153. Britigan, E.M.C.; Wan, J.; Zasadil, L.M.; Ryan, S.D.; Weaver, B.A. The ARF tumor suppressor prevents chromosomal instability and ensures mitotic checkpoint fidelity through regulation of Aurora, B. Mol. Biol. Cell 2014, 25, 2761-2773. [CrossRef] [PubMed] 
154. Healy, J.; Bélanger, H.; Beaulieu, P.; Larivière, M.; Labuda, D.; Sinnett, D. Promoter SNPs in G1/S checkpoint regulators and their impact on the susceptibility to childhood leukemia. Blood 2007, 109, 683-692. [CrossRef] [PubMed]

155. Maloney, K.W.; McGavran, L.; Odom, L.F.; Hunger, S.P. Acquisition of p16(INK4A) and p15(INK4B) gene abnormalities between initial diagnosis and relapse in children with acute lymphoblastic leukemia. Blood 1999, 93, 2380-2385. [CrossRef] [PubMed]

156. Carter, T.L.; Reaman, G.H.; Kees, U.R. INK4A/ARF deletions are acquired at relapse in childhood acute lymphoblastic leukaemia: A paired study on 25 patients using real-time polymerase chain reaction. Br. J. Haematol. 2001, 113, 323-328. [CrossRef] [PubMed]

157. Davidsson, J.; Paulsson, K.; Lindgren, D.; Lilljebjörn, H.; Chaplin, T.; Forestier, E.; Andersen, M.K.; Nordgren, A.; Rosenquist, R.; Fioretos, T; et al. Relapsed childhood high hyperdiploid acute lymphoblastic leukemia: Presence of preleukemic ancestral clones and the secondary nature of microdeletions and RTK-RAS mutations. Leukemia 2010, 24, 924-931. [CrossRef] [PubMed]

158. Yu, J.; Waanders, E.; van Reijmersdal, S.V.; Antić, Ž.; van Bosbeek, C.M.; Sonneveld, E.; de Groot, H.; Fiocco, M.; van Kessel, A.G.; van Leeuwen, F.N.; et al. Upfront Treatment Influences the Composition of Genetic Alterations in Relapsed Pediatric B-Cell Precursor Acute Lymphoblastic Leukemia. HemaSphere 2020, 4. [CrossRef]

159. Soenen, V.; Lepelley, P.; Gyan, E.; Preudhomme, C.; Lai, J.L.; Bauters, F.; Fenaux, P.; Quesnel, B. Prognostic significance of p16INK4a immunocytochemistry in adult ALL with standard risk karyotype. Leukemia 2001, 15, 1054-1059. [CrossRef]

160. Kuster, L.; Grausenburger, R.; Fuka, G.; Kaindl, U.; Krapf, G.; Inthal, A.; Mann, G.; Kauer, M.; Rainer, J.; Kofler, R.; et al. ETV6/RUNX1-positive relapses evolve from an ancestral clone and frequently acquire deletions of genes implicated in glucocorticoid signaling. Blood 2011, 117, 2658-2667. [CrossRef]

161. Spinella, J.-F.; Richer, C.; Cassart, P.; Ouimet, M.; Healy, J.; Sinnett, D. Mutational dynamics of early and late relapsed childhood ALL: Rapid clonal expansion and long-term dormancy. Blood Adv. 2018, 2, 177-188. [CrossRef]

162. Schroeder, M.P.; Bastian, L.; Eckert, C.; Gökbuget, N.; James, A.R.; Tanchez, J.O.; Schlee, C.; Isaakidis, K.; Häupl, B.; Baum, K.; et al. Integrated analysis of relapsed B-cell precursor Acute Lymphoblastic Leukemia identifies subtype-specific cytokine and metabolic signatures. Sci. Rep. 2019, 9, 1-11.

163. Williams, R.T.; Den Besten, W.; Sherr, C.J. Cytokine-dependent imatinib resistance in mouse BCR-ABL+, Arf-null lymphoblastic leukemia. Genes Dev. 2007, 21, 2283-2287. [CrossRef] [PubMed]

164. Sawai, C.M.; Freund, J.; Oh, P.; Ndiaye-Lobry, D.; Bretz, J.C.; Strikoudis, A.; Genesca, L.; Trimarchi, T.; Kelliher, M.A.; Clark, M.; et al. Therapeutic Targeting of the Cyclin D3:CDK4/ 6 Complex in T Cell Leukemia. Cancer Cell 2012, 22, 452-465. [CrossRef] [PubMed]

165. Sheppard, K.E.; McArthur, G.A. The cell-cycle regulator CDK4: An emerging therapeutic target in melanoma. Clin. Cancer Res. 2013, 19, 5320-5328. [CrossRef] [PubMed]

166. Dickson, M.A. Molecular pathways: CDK4 inhibitors for cancer therapy. Clin. Cancer Res. 2014, 20, 3379-3383. [CrossRef] [PubMed]

167. Dean, J.L.; Thangavel, C.; McClendon, A.K.; Reed, C.A.; Knudsen, E.S. Therapeutic CDK4/6 inhibition in breast cancer: Key mechanisms of response and failure. Oncogene 2010, 29, 4018-4032. [CrossRef]

168. Raub, T.J.; Wishart, G.N.; Kulanthaivel, P.; Staton, B.A.; Ajamie, R.T.; Sawada, G.A.; Gelbert, L.M.; Shannon, H.E.; SanchezMartinez, C.; De Dios, A. Exposure of Two Selective Dual CDK4 and CDK6 Inhibitors and the Antitumor Activity of CDK4 and CDK6 Inhibition in Combination with Temozolomide in an Intracranial Glioblastoma Xenograft. Drug Metab. Dispos. 2015, 43, 1360-1371. [CrossRef]

169. Fry, D.W.; Harvey, P.J.; Keller, P.R.; Elliott, W.L.; Meade, M.; Trachet, E.; Albassam, M.; Zheng, X.; Leopold, W.R.; Pryer, N.K.; et al. Specific inhibition of cyclin-dependent kinase $4 / 6$ by PD 0332991 and associated antitumor activity in human tumor xenografts. Mol. Cancer Ther. 2004, 3, 1427-1438.

170. Kim, S.; Tiedt, R.; Loo, A.; Horn, T.; Delach, S.; Kovats, S.; Haas, K.; Engstler, B.S.; Cao, A.; Pinzon-Ortiz, M.; et al. The potent and selective cyclin-dependent kinases 4 and 6 inhibitor ribociclib (LEE011) is a versatile combination partner in preclinical cancer models. Oncotarget 2018, 9, 35226. [CrossRef] 